Review

\title{
Changes in Access to Health Services during the COVID-19 Pandemic: A Scoping Review
}

\author{
Georgina Pujolar*(D), Aida Oliver-Anglès (D), Ingrid Vargas (D) and María-Luisa Vázquez
}

check for

updates

Citation: Pujolar, G.; Oliver-Anglès,

A.; Vargas, I.; Vázquez, M.-L.

Changes in Access to Health Services during the COVID-19 Pandemic: A Scoping Review. Int. J. Environ. Res. Public Health 2022, 19, 1749. https:// doi.org/10.3390/ijerph19031749

Academic Editors:

Rosa Urbanos-Garrido and

Alexandrina Stoyanova

Received: 29 November 2021

Accepted: 30 January 2022

Published: 3 February 2022

Publisher's Note: MDPI stays neutral with regard to jurisdictional claims in published maps and institutional affiliations.

Copyright: (C) 2022 by the authors. Licensee MDPI, Basel, Switzerland. This article is an open access article distributed under the terms and conditions of the Creative Commons Attribution (CC BY) license (https:// creativecommons.org/licenses/by/ $4.0 /)$.
Health Policy Research Unit (SEPPS), Consorci de Salut i Social de Catalunya, 08022 Barcelona, Spain; aoliver@consorci.org (A.O.-A.); ivargas@consorci.org (I.V.); mlvazquez@consorci.org (M.-L.V.)

* Correspondence: ggpujolar@gmail.com

Abstract: The COVID-19 pandemic and the measures adopted are having a profound impact on a major goal of public healthcare systems: universal access to health services. The objective is to synthesize the available knowledge on access to health care for non-COVID-19 conditions and to identify knowledge gaps. A scoping review was conducted searching different databases (Medline, Google Scholar, etc.) for original articles published between December 2019 and September 2021. A total of 53 articles were selected and analyzed using the Aday and Andersen framework as a guide. Of these, 37 analyzed changes in levels of use of health services, 15 focused on the influencing factors and barriers to access, and 1 studied both aspects. Most focused on specific diseases and the early stages of the pandemic, based on a review of records. Analyses of the impact on primary care services' use, unmet needs or inequalities in access were scarce. A generalized reduction in the use of health services was described. The most frequent access barrier described for non-COVID-19 conditions related to the services was a lack of resources, while barriers related to the population were predisposing (fear of contagion, stigma, or anticipating barriers) and enabling characteristics (worse socioeconomic status and an increase in technological barriers). In conclusion, our results show a general reduction in services' use in the early stages of the pandemic, as well as new barriers to access and the exacerbation of existing ones. In view of these results, more studies are required on the subsequent stages of the pandemic, to shed more light on the factors that have influenced access and the pandemic's impact on equity of access.

Keywords: COVID-19; health services' accessibility; delivery of health care; health care inequalities

\section{Introduction}

The pandemic due to coronavirus SARS-CoV-2 (COVID-19), a novel virus initially reported in December 2019 [1], was declared by the World Health Organization (WHO) on 11 March 2020. It has had an adverse effect worldwide on many different spheres of society, including the economy and public health. The current COVID-19 pandemic and the diverse strategies that have been adopted to tackle it are forcing changes in access to health services for other conditions, potentially producing an impact on the health of the population above and beyond that caused by COVID-19 itself [2-6].

In this regard, some strategies taken to combat soaring COVID-19 infection rates may have negatively affected access to health services for other conditions. Firstly, at the health services level, one of the most influential measures was the classification of services as essential or non-essential, following WHO guidelines, which allowed resources to be redirected to the pandemic response. However, this has also caused cancellations or delays in elective and non-urgent procedures [3,5-7], despite many countries implementing strategies to mitigate the impact of these disruptions (e.g., online healthcare visits) [4,5], Another significant measure was social distancing to reduce interaction between people, including nationwide partial or complete lockdowns, schools and non-essential business 
closures, and instructions to stay at home, which in some cases has erected a barrier in terms of mobility to entry the health services [8].

Another indirect effect of the pandemic, the economic crisis stemming from the substantial curtailment of economic activity, and the ensuing rise in unemployment and loss of household income, have aggravated associated access barriers (loss of health coverage, difficulties in making copayments or obtaining transport to services), thereby accentuating existing inequalities in access, as studies on previous economic crises have shown [9]. Although it is necessary to evaluate which population groups have been particularly affected in terms of access to care and how the determining factors interact with each other, there are some signs - including early evidence and experiences from previous crises-to indicate that vulnerable population groups (populations with low socioeconomic status, the elderly, chronic patients or those with severe conditions, migrants from low-income countries) suffer a greater impact [9-14].

In short, as in other epidemics and previous outbreaks, the health repercussions of the current pandemic are not confined solely to COVID-19 infection and mortality. They also include indirect negative effects on healthcare access and on the quality of curative and preventive care provided for other conditions, and the exacerbation of difficulties and barriers related to socioeconomic factors [15-17]. The scientific evidence accumulated from previous experiences, such as severe acute respiratory syndrome or SARS (2002-2003), Middle East respiratory syndrome or MERS (2012), Ebola (2014-2016; 2018-present), and the Zika virus (2015-2016) [18-20], shows a decrease in the utilization of health services (e.g. outpatient care, hospital admissions, elective surgeries [20-23]) that is attributed to changes made to the health services in response to public health emergencies, as well as to fear of contagion among the population [21,24]. This may in turn have had an impact on increasing the burden of disease and mortality in the months following an epidemic outbreak [6,20,25-27].

While a plethora of scientific papers have been published on COVID-19 since the start of the pandemic, studies on its impact on access to health services have not been so plentiful. A few literature reviews have been found that summarize changes in health services due to the pandemic, focusing mainly on the adoption of telemedicine [28-32] and the impact of the pandemic on different aspects, among others, the use of certain specific services, such as maternal and child health care [33], child vaccination [34], or chronic diseases [35,36], in the initial stages of the pandemic. Although we are still at the pandemic management stage, a synthesis of the scientific evidence accumulated to date on the impact on access to health care in different contexts, in addition to detailed monitoring of the performance of services, may help decision makers to make healthcare systems more resilient in current and future emergencies and protect public health and access to health care.

Access to care involves many highly interdependent factors and stakeholders at play [37]. This study takes as its framework of reference one of the most frequently used models for the analysis of access to health services [38], that of Aday and Andersen [39]. This model distinguishes between realized access (effective utilization of the services) and potential access (determinants of access), differentiating between factors related to the services and to the population. The realized access analysis takes into account the type, place, motive of the visit (preventive or curative), and care outcomes, while potential access analysis takes into account the characteristics of the services (availability of resources and organization) and those of the population (predisposing factors: sociodemographic factors, beliefs, attitudes, and knowledge of the health system; enabling factors: income and type of insurance; health needs). Health policies, programs, or interventions can in turn affect access barriers related to the health services or changing (mutable) characteristics of the population $[39,40]$. Aday and Andersen's framework is more comprehensive and exhaustive than other analytical models [41-43], which focus either on the entry to health services or on the characteristics of services and how they adjust to the characteristics of the population. Thus, it offers an appropriate approach for identifying existing knowledge 
gaps in the literature on access and to analyzing different types of barriers and factors that influence the use of health services.

The aim of this article is to synthesize the knowledge accrued from the onset of the pandemic in March 2020 through to September 2021 on the impact of the COVID-19 pandemic on access to health services (including primary care, outpatient secondary care, and inpatient care) for non-COVID-related conditions, and to identify knowledge gaps on these subjects.

\section{Materials and Methods}

A scoping review of the scientific literature [44] was carried out, following the PRISMA guide [45], to identify original articles on the impact of the COVID-19 pandemic on access to health services for non-COVID-related conditions.

In our bibliographic search, several digital databases were consulted to minimize the risk of overlooking any relevant studies: Medline, Google Scholar, SCiELO, and Web of Science. The search was performed over two separate periods: 22 January 2021-31 March 2021 and 22 September 2021-10 October 2021. In the Medline database, using a thesaurus, MeSH terms were employed for: (a) COVID-19: "Coronavirus Infections", "Coronavirus", "COVID-19", "SARS-CoV-2"; (b) access to health services: "Health services availability", "Health services needs and demand", "Healthcare disparities", "Needs assessment, healthcare", "Health policy", "Equipment and Supplies Utilization”, "Facilities and Services Utilization" (see Appendix A for more detail). In the other databases free text terms were used: (a) COVID-19: "coronavirus disease", "COVID-19"; (b) access to health services: "health services accessibility", "accessibility", "accessing", "access", "utilization", "delivery of health care", "healthcare services", among others. Word groups were combined using Boolean operators "AND" and "OR" in order to identify the literature in the databases consulted and select those studies referring to the impact of COVID-19 on access to health services. The search was complemented with a manual review of references cited within the selected articles.

We selected original articles published in Spanish or English from December 2019 to September 2021 - with no filters for geographical area or motive for access (apart from being unrelated to COVID-19) — that used qualitative and/or quantitative methods and analyzed or described changes in access to health services in the context of the COVID19 pandemic. The initial selection of studies to review was performed through title and abstract screening. Where there was any doubt about whether to include a study, this was discussed with another researcher in the team.

Following Aday and Andersen's framework [39,40], the selected studies were classified into two groups: those that analyzed utilization of services (realized access) and those that explored factors that influence access (potential access). Any studies on realized access that did not use medical records, administrative/institutional databases, or patient surveys as their data source were excluded. A data extraction protocol was produced to include information related to methodological aspects (methods, period of analysis, study area, population, sample, type of health service) and study results (according to the variables or dimensions of analysis). This information was extracted from the articles and presented in tables, grouped according to type of access, and ordered by type of health service. The results were summarized according to the analytical framework, which was also used to identify any gaps in knowledge related to the aspects studied.

\section{Results}

From the search results, 242 articles were identified for title and abstract screening, and 95 for full-text review. A total of 53 articles met the inclusion criteria for analysis (Figure 1). 


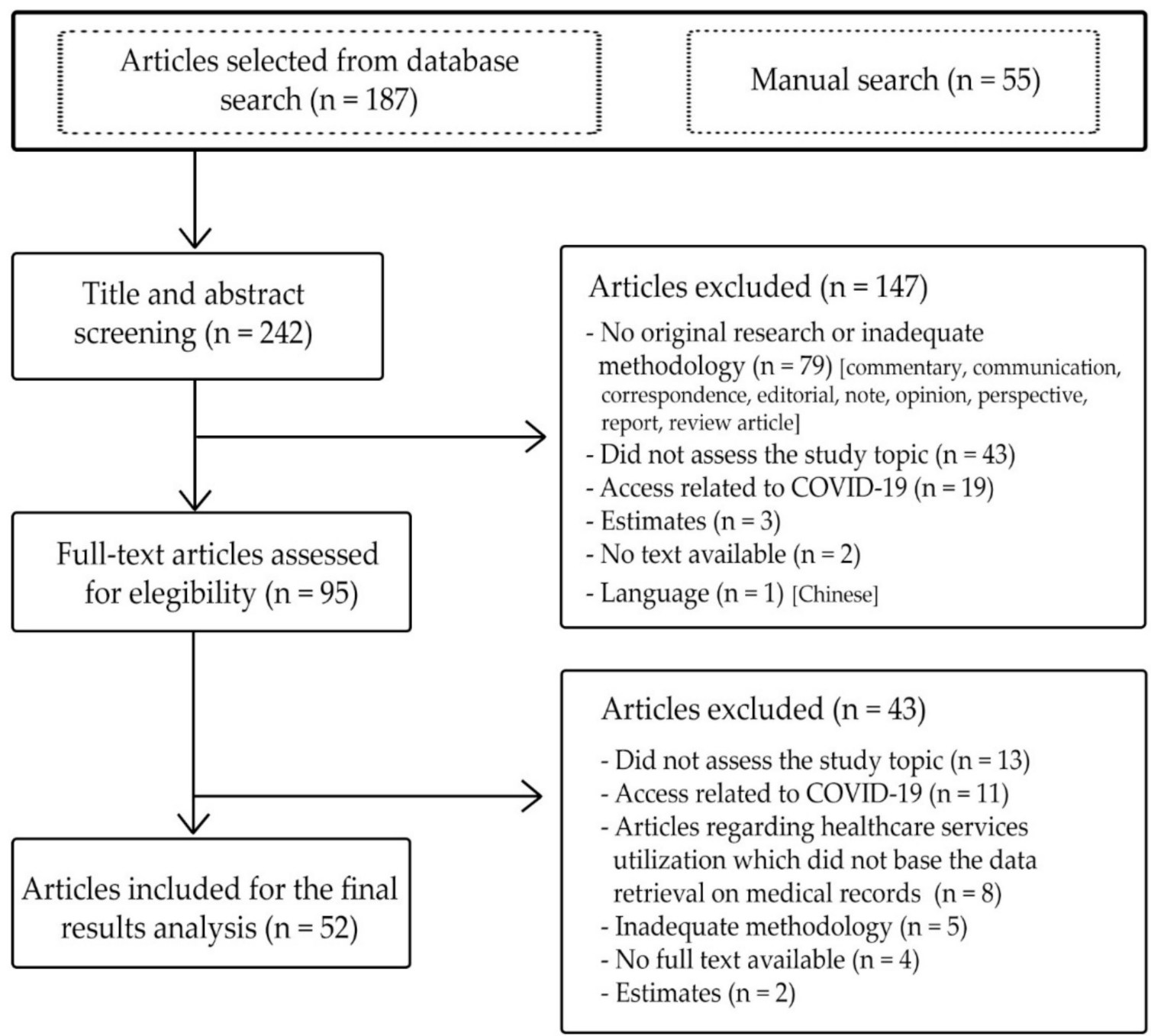

Figure 1. Flow chart of study selection process.

Of the 53 articles selected, 37 analyzed changes in realized access applying quantitative methods [46-82], through the analysis of medical records (Table 1), 8 analyzed changes in potential access [83-90] via surveys of different population groups, except for one that did the same via analysis of medical records [90] (Table 2), 7 used qualitative methods to analyze the impact on potential access [91-97] (Table 3), and, finally, 1 study analyzed changes in both realized and potential access [98] using mixed methods (analysis of medical records and semi-structured interviews). Only six of the studies that explored changes in potential access included professionals from the health centers analyzed as a study population, $[87,89,92,93,97,98]$, while the rest focused on patients or the general population. 
Table 1. Changes in the utilization of health services and influencing factors during the COVID-19 pandemic in 2020.

\begin{tabular}{|c|c|c|c|c|c|c|}
\hline $\begin{array}{c}\text { First Author, } \\
\text { Year }\end{array}$ & Data Source & Study Area & $\begin{array}{l}\text { Study Population } \\
\text { and Sample }\end{array}$ & Study Period & Health Service & Main Results \\
\hline Abebe, 2021 & $\begin{array}{l}\text { Medical records from } \\
\text { Tikur Anbessa } \\
\text { Specialized Hospital }\end{array}$ & Ethiopia & $\begin{array}{c}\text { Follow-up visits }(n=7717) \\
\text { and admissions }(n=3310) \\
\text { between December } \\
\text { 2018-June } 2019 \text { and } \\
\text { follow-up visits }(n=4597) \\
\text { and admissions }(n=2383) \\
\text { between December } \\
\text { 2019-June } 2020\end{array}$ & $\begin{array}{l}\text { December-June } \\
\text { 2018-2019 vs. } \\
\text { 2019-2020 }\end{array}$ & General $^{1}$ & $\begin{array}{l}\text { Reduction in follow-up visits }(40 \%) \text { and } \\
\text { admissions ( } 28 \%) \text { from March } 2020, \\
\text { compared with the same period in } 2019 . \\
\text { Visits reduced especially among } \\
\text { patients receiving renal, neurological, } \\
\text { cardiac, and antiretroviral treatment } \\
\text { (68-51.4\%). No significant changes } \\
\text { were observed among pediatric and } \\
\text { adult admissions. }\end{array}$ \\
\hline Howarth, 2021 & $\begin{array}{l}\text { Private health insurer } \\
\text { claims records }\end{array}$ & $\begin{array}{l}\text { United Kingdom } \\
\text { (UK) }\end{array}$ & $\begin{array}{c}\text { Claims to private health } \\
\text { centers in the United } \\
\text { Kingdom }(n=\text { aggregated } \\
\text { data })^{2}\end{array}$ & $\begin{array}{c}\text { January } 2018-\text { August } \\
2020\end{array}$ & General & $\begin{array}{l}\text { Reduction in healthcare claims in } \\
\text { general (70\%) from March } 2020 \\
\text { (lockdown), undergoing an increase } \\
\text { over the following months without } \\
\text { reaching the pre-pandemic levels. Visits } \\
\text { in mental health differed from the } \\
\text { general pattern, with increased } \\
\text { utilization (20\%) compared to previous } \\
\text { years. }{ }^{3}\end{array}$ \\
\hline Siedner, 2020 & $\begin{array}{c}\text { Africa Health Research } \\
\text { Institute Demographic } \\
\text { Health Surveillance } \\
\text { System }\end{array}$ & $\begin{array}{l}\text { KwaZulu Natal, } \\
\text { South Africa }\end{array}$ & $\begin{array}{l}\text { Visit to rural clinics } \\
\quad(n=46,523)^{2}\end{array}$ & $\begin{array}{l}\text { January-March vs. } \\
\text { March-April vs. } \\
\text { May-June } 2018 \text { vs. } \\
2019 \text { vs. } 2020\end{array}$ & General & $\begin{array}{l}\text { Reduction in the number of childcare } \\
\text { visits ( } 50 \% \text { ), including preventive } \\
\text { procedures, and sustained utilization of } \\
\text { HIV services and adult outpatient } \\
\text { clinics during the national lockdown } \\
\text { (March-June 2020), compared to the } \\
\text { previous periods. No significant } \\
\text { changes were observed at a general } \\
\text { level in the use of services. Childcare } \\
\text { visits recovered over the following } \\
\text { three months to pre-lockdown levels. }\end{array}$ \\
\hline
\end{tabular}


Table 1. Cont.

\begin{tabular}{|c|c|c|c|c|c|c|}
\hline $\begin{array}{l}\text { First Author, } \\
\text { Year }\end{array}$ & Data Source & Study Area & $\begin{array}{l}\text { Study Population } \\
\text { and Sample }\end{array}$ & Study Period & Health Service & Main Results \\
\hline Whaley, 2020 & $\begin{array}{l}\text { Aggregate data on } \\
\text { health insurance claims }\end{array}$ & $\begin{array}{l}\text { United States of } \\
\text { America (USA) }\end{array}$ & $\begin{array}{l}\text { Population with health } \\
\text { insurance in } 2018 \text { ( } n=5.6 \\
\text { million), } 2019(n=6.4 \\
\text { million), and } 2020 \text { ( } n=6.8 \\
\text { million) }\end{array}$ & $\begin{array}{c}\text { January-February } \\
\text { and March-April } \\
2018 \text { vs. } 2019 \text { vs. } \\
2020\end{array}$ & General & $\begin{array}{l}\text { Reduction in the utilization of a number } \\
\text { of preventive services, elective } \\
\text { procedures, and in-person office visits } \\
\text { (different values according to the type } \\
\text { of service or procedure) in March and } \\
\text { April 2020. No significant changes in } \\
\text { emergency care, maternal health, or } \\
\text { medication prescription were observed. } \\
\text { Utilization of telemedicine visits } \\
\text { increased. } \\
\text { Associated factors (AF): patients living } \\
\text { in poor areas and most } \\
\text { ethnic/racialized minorities were less } \\
\text { likely to experience a reduction in } \\
\text { in-person visits but also to have fewer } \\
\text { visits of telemedicine. }\end{array}$ \\
\hline Zhang, 2020 & $\begin{array}{l}\text { Aggregate data on China } \\
\text { UnionPay Healthcare } \\
\text { bank transactions }\end{array}$ & China & $\begin{array}{l}\text { Health care transactions } \\
\qquad(n=300 \text { million })^{2}\end{array}$ & $\begin{array}{l}\text { January-March } 2019 \\
\text { vs. December } \\
\text { 2019-February } 2020 \\
\text { vs. November } \\
\text { 2019-April } 2020\end{array}$ & General & $\begin{array}{l}\text { Reduction in daily expenditure on } \\
\text { health }(37.8 \%) \text { and in number of visits } \\
\text { to health services }(40.8 \%) \text { from January } \\
2020 \text {. } \\
\text { AF: higher probability of utilization of } \\
\text { health services was associated with } \\
\text { cities with lower rates of COVID-19 } \\
\text { cases, less strict measures, and not } \\
\text { located in the western region of the } \\
\text { country. }\end{array}$ \\
\hline Ojetti, 2020 & $\begin{array}{c}\text { Medical records from an } \\
\text { urban tertiary teaching } \\
\text { hospital }\end{array}$ & Italy & $\begin{array}{l}\text { Admissions to the } \\
\text { emergency department (ED) } \\
(n=16,281)\end{array}$ & $\begin{array}{l}\text { February-March } \\
2019 \text { vs. } 2020\end{array}$ & ED & $\begin{array}{l}\text { Reduction in ED admissions ( } 37.6 \% \text { ) for } \\
\text { several diseases in } 2020 \text { compared to } \\
\text { 2019. There was an increase in triage } \\
\text { emergency levels for ED admissions } \\
\text { and in hospitalization rates (different } \\
\text { values according to the type of } \\
\text { admission). }\end{array}$ \\
\hline
\end{tabular}


Table 1. Cont.

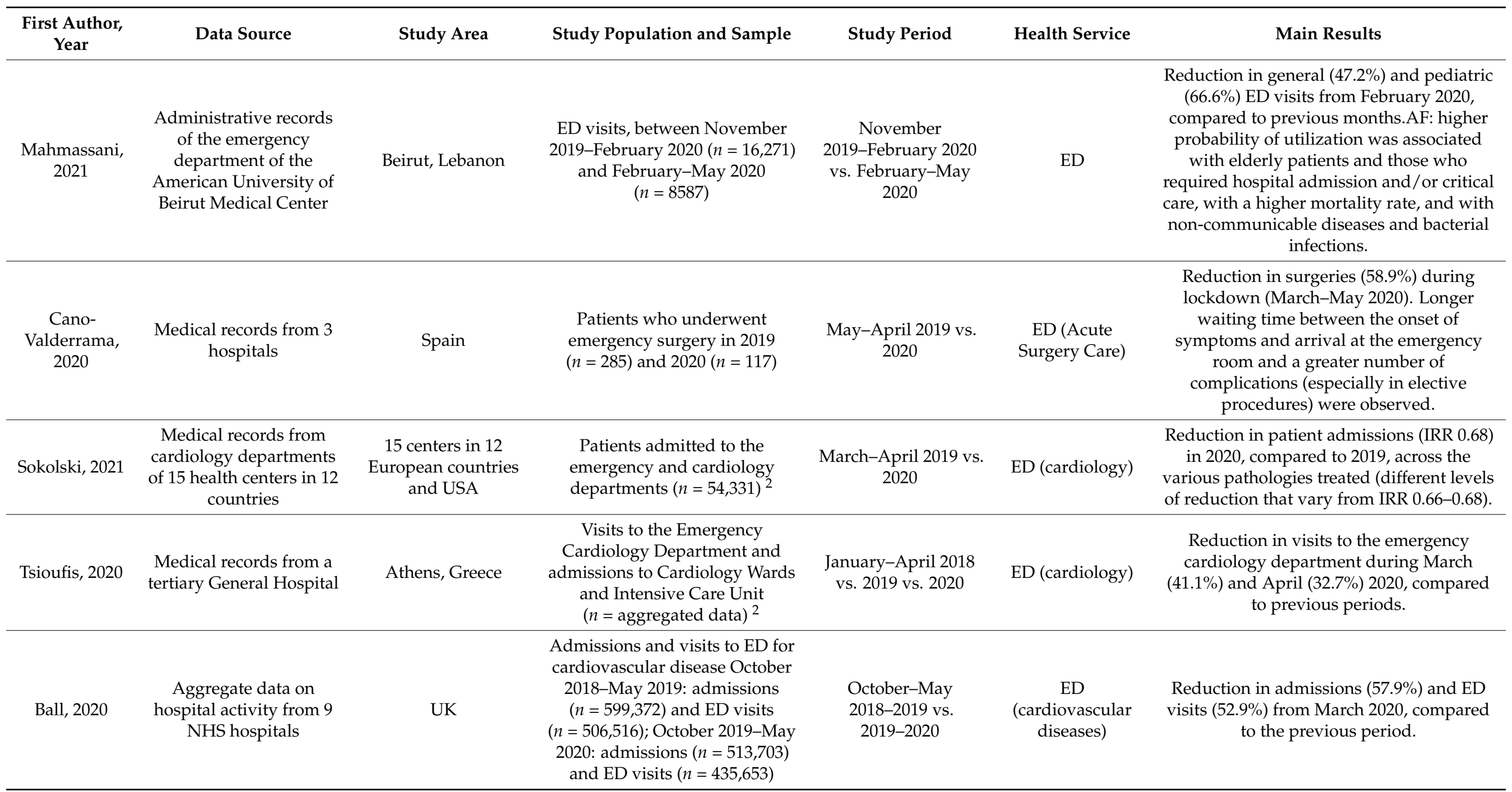


Table 1. Cont.

\begin{tabular}{|c|c|c|c|c|c|c|}
\hline $\begin{array}{c}\text { First Author, } \\
\text { Year }\end{array}$ & Data Source & Study Area & $\begin{array}{l}\text { Study Population } \\
\text { and Sample }\end{array}$ & Study Period & Health Service & Main Results \\
\hline Choi, 2021 & $\begin{array}{c}\text { Medical records from } 6 \\
\text { hospitals }\end{array}$ & South Korea & $\begin{array}{c}\text { Patients under } 18 \text { years of } \\
\text { age seen in pediatric ED } \\
\left(n={\text { aggregated data })^{2}}^{2}\right.\end{array}$ & $\begin{array}{c}\text { January } \\
\text { 2017-November } 2020\end{array}$ & ED (pediatrics) & $\begin{array}{l}\text { Reduction in pediatric ED visits }(43.6 \%) \\
\text { in } 2020 \text { compared to previous years, } \\
\text { although a significantly increased } \\
\text { proportion of visits for injuries (9.4\%) } \\
\text { during the COVID-19 outbreak. } \\
\text { AF: higher probability of use was } \\
\text { associated with male patients. }\end{array}$ \\
\hline Finkelstein, 2021 & $\begin{array}{l}\text { Medical records from the } \\
\text { Pediatric Emergency } \\
\text { Research Network }\end{array}$ & Canada & $\begin{array}{l}\text { Patients under } 18 \text { years of } \\
\text { age who attended the ED in } \\
2018(n=211,085), 2019 \\
(n=207,673), \text { and } 2020 \\
(n=159,049)\end{array}$ & $\begin{array}{c}\text { January } \\
\text { 2018-January } 2020 \text { vs. } \\
\text { January-March } 2020 \\
\text { vs. March-April } 2020\end{array}$ & ED (pediatrics) & $\begin{array}{l}\text { Reduction in weekly pediatric ED visits } \\
(58 \%) \text {, in re-visits ( } 55 \% \text { ), in visits to } \\
\text { trauma (increase in proportion of total } \\
\text { visits), and to mental health (56 to } 60 \% \\
\text { depending on the age group) from } \\
\text { March 2020, compared to previous } \\
\text { years. Increase in the proportion of } \\
\text { ward (OR 1.39) and ICU (OR 1.2) } \\
\text { admissions. }\end{array}$ \\
\hline Goldman, 2020 & $\begin{array}{c}\text { Medical records from } 18 \\
\text { pediatric emergency } \\
\text { departments }\end{array}$ & $\begin{array}{l}\text { British Columbia, } \\
\text { Canada }\end{array}$ & $\begin{array}{c}\text { Pediatric ED visits }(0-16 \\
\text { years): March-April } 2019 \\
(n=22,654) ; \text { December } \\
\text { 2019-January 2020 } \\
(n=31,525) ; \text { January-March } \\
\text { 2020 }(n=26,654) ; \\
\text { March-April } 2020(n=7535)\end{array}$ & $\begin{array}{l}\text { March-April } 2019 \text { vs. } \\
\text { December } \\
\text { 2019-January } 2020 \text { vs. } \\
\text { January-March } 2020 \\
\text { vs. March-April } 2020\end{array}$ & ED (pediatrics) & $\begin{array}{c}\text { Reduction in visits to pediatric } \\
\text { emergencies ( } 57 \text { to } 70 \% \text { ), especially } \\
\text { during the peak of the pandemic } \\
\text { (March-April 2020), compared to } \\
\text { previous periods. Admission } \\
\text { proportion almost doubled ( } 4 \% \\
\text { pre-pandemic to } 7 \% \text { during the peak } \\
\text { pandemic period). Average acuity of } \\
\text { illness was higher during the pandemic } \\
\text { period. }\end{array}$ \\
\hline
\end{tabular}


Table 1. Cont.

\begin{tabular}{|c|c|c|c|c|c|c|}
\hline $\begin{array}{l}\text { First Author, } \\
\text { Year }\end{array}$ & Data Source & Study Area & $\begin{array}{l}\text { Study Population } \\
\text { and Sample }\end{array}$ & Study Period & Health Service & Main Results \\
\hline Percul, 2021 & $\begin{array}{l}\text { Medical records from the } \\
\text { Italian Hospital of } \\
\text { Buenos Aires }\end{array}$ & $\begin{array}{l}\text { Buenos Aires, } \\
\text { Argentina }\end{array}$ & $\begin{array}{l}\text { Patients under } 18 \text { years of } \\
\text { age treated for appendicitis } \\
\text { in } 2019(n=117) \text { and } 2020 \\
\qquad(n=50)\end{array}$ & $\begin{array}{l}\text { March-August } 2019 \\
\text { vs. } 2020\end{array}$ & $\mathrm{ED}$ (pediatrics) & $\begin{array}{l}\text { Reduction in appendicitis admissions ( } 25 \%) \\
\text { in } 2020 \text { compared to } 2019 \text {, with no } \\
\text { significant differences in the mean time to } \\
\text { consultation. An increase in peritonitis } \\
\text { cases was observed, although the incidence } \\
\text { of complications decreased (not significant } \\
\text { in both cases). }\end{array}$ \\
\hline Kute, 2021 & $\begin{array}{l}\text { Medical records from the } \\
\text { Kidney Disease Institute } \\
\text { and Research Center }\end{array}$ & India & $\begin{array}{l}\text { Patients treated in kidney } \\
\text { disease services in } 2019 \\
(n=109,572) \text { and } 2020 \\
(n=87,714)\end{array}$ & $\begin{array}{c}\text { January } \\
\text { 2019-December } 2020\end{array}$ & SC: nephrology & $\begin{array}{l}\text { Reduction in visits and admissions, } \\
\text { transplants, and other elective procedures } \\
\text { (different values according to the type of } \\
\text { service or procedure) in 2020, compared to } \\
\text { 2019. Slight increase in activity between } \\
\text { July and October, without reaching } \\
\text { previous levels, with a further reduction } \\
\text { starting in November 2020. }{ }^{3}\end{array}$ \\
\hline Morris, 2021 & $\begin{array}{c}\text { NHS population-based } \\
\text { datasets }\end{array}$ & UK & $\begin{array}{c}\text { Patients referred for } \\
\text { suspected or diagnosed } \\
\text { colorectal cancer } \\
\text { (n= monthly average mean) } \\
2\end{array}$ & $\begin{array}{l}\text { January-December } \\
2019 \text { vs. } \\
\text { January-October } \\
2020\end{array}$ & SC: oncology & $\begin{array}{l}\text { Reduction in the monthly number of } \\
\text { referrals for suspected cancer }(63 \%) \text { and for } \\
\text { treatment }(22 \%) \text {, colonoscopies }(92 \%) \text {, and } \\
\text { surgeries ( } 31 \%) \text { from April 2020, compared } \\
\text { to } 2019 \text { and the preceding months. Relative } \\
\text { increase in radiotherapy use ( } 44 \% \text { ) due to } \\
\text { increased use of short-course regimens. } \\
\text { Monthly rate of referrals and other } \\
\text { procedures returned to } 2019 \text { levels by } \\
\text { October } 2020 .\end{array}$ \\
\hline
\end{tabular}


Table 1. Cont.

\begin{tabular}{|c|c|c|c|c|c|c|}
\hline $\begin{array}{c}\text { First Author, } \\
\text { Year }\end{array}$ & Data Source & Study Area & $\begin{array}{c}\text { Study Population } \\
\text { and Sample }\end{array}$ & Study Period & Health Service & Main Results \\
\hline Pareek, 2021 & $\begin{array}{l}\text { Medical records from the } \\
\text { Gujarat Cancer Research } \\
\text { Institute }\end{array}$ & Gujarat, India & $\begin{array}{l}\text { Cancer patients visits to the } \\
\text { oncology department } \\
\text { between January-March } \\
(n=4363) \text { and March-May } \\
(n=895) 2020\end{array}$ & $\begin{array}{l}\text { January-March vs. } \\
\text { March-May } 2020\end{array}$ & SC: oncology & $\begin{array}{l}\text { Reduction in visits from lockdown } \\
\text { (different values according to the type } \\
\text { of cancer) in March 2020, compared to } \\
\text { the previous months. }{ }^{3}\end{array}$ \\
\hline Shi, 2021 & $\begin{array}{l}\text { Medical records from } 13 \\
\text { pediatric tertiary cardiac } \\
\text { centers }\end{array}$ & China & $\begin{array}{l}\text { Patients who underwent } \\
\text { cardiac surgery in } 2018 \\
(n=19,398), 2019(n=19,620) \\
\quad \text { and } 2020(n=4740)\end{array}$ & $\begin{array}{l}\text { January-April } 2018 \\
\text { vs. } 2019 \text { vs. } 2020\end{array}$ & SC: pediatric surgery & $\begin{array}{l}\text { Reduction in the total surgical volume } \\
\text { median ( } 25 \text { cases) compared to } 2018 \\
\text { (148 cases) and } 2019 \text { (158 cases). } \\
\text { Increase in the proportion of emergency } \\
\text { operations (6.3\%) during 2020, } \\
\text { compared to previous years. Increase in } \\
\text { patients followed-up via the internet or } \\
\text { phone ( } 26.4 \% \text { in } 2020 \text { vs } 9.5 \% \text { and } 8.9 \% \\
\text { in } 2019 \text { and } 2018) \text {. }\end{array}$ \\
\hline Ambrosetti, 2021 & $\begin{array}{l}\text { Medical records from the } \\
\text { University Hospital of } \\
\text { Geneva }\end{array}$ & Geneva, Switzerland & $\begin{array}{l}\text { Admissions to the } \\
\text { psychiatric ED from April to } \\
\text { May } 2016(n=702) \text { and } 2020 \\
\qquad(n=579)\end{array}$ & $\begin{array}{l}\text { April-May } 2016 \text { vs. } \\
2020\end{array}$ & SC: psychiatry & $\begin{array}{l}\text { Reduction in admissions (17.5\%) in } \\
\text { psychiatric ED in } 2020 \text { compared to } \\
2016 \text {. } \\
\text { AF: the probability to be admitted was } \\
\text { more associated with severe } \\
\text { psychopathologies and single patients, } \\
\text { who arrived by ambulance, with } \\
\text { suicidal behaviors, behavioral } \\
\text { disorders, and psychomotor agitation, } \\
\text { and were more likely to be involuntarily } \\
\text { hospitalized after consultation in ED. }\end{array}$ \\
\hline Aragona, 2020 & $\begin{array}{l}\text { Medical records from the } \\
\text { National Institute for } \\
\text { Health, Migration and } \\
\text { Poverty }\end{array}$ & Italy & $\begin{array}{c}\text { Patients in a vulnerable } \\
\text { situation who received at } \\
\text { least one psychiatric } \\
\text { intervention from February } \\
(n=286) \text { or March }(n=269) \\
\text { from } 2017 \text { to } 2020^{2}\end{array}$ & $\begin{array}{l}\text { February-March } \\
2017 \text { vs. } 2018 . \text { vs. } \\
2019 \text { vs. } 2020\end{array}$ & SC: psychiatry & $\begin{array}{c}\text { Reduction in visits (46.6\%) to mental } \\
\text { health in March } 2020 \text {. Follow-up visits } \\
\text { of patients from February to March } \\
\text { decreased more (17.5\% patients), } \\
\text { compared to previous years ( } 30 \% \\
\text { patients). }\end{array}$ \\
\hline
\end{tabular}


Table 1. Cont.

\begin{tabular}{|c|c|c|c|c|c|c|}
\hline $\begin{array}{c}\text { First Author, } \\
\text { Year }\end{array}$ & Data Source & Study Area & $\begin{array}{l}\text { Study Population } \\
\text { and Sample }\end{array}$ & Study Period & Health Service & Main Results \\
\hline Jesenšek, 2021 & $\begin{array}{l}\text { Medical records from the } \\
\text { Institute of Physical } \\
\text { Medicine and } \\
\text { Rehabilitation }\end{array}$ & Slovenia & $\begin{array}{l}\text { Patients referred to } \\
\text { rehabilitation in } 2019 \\
(n=4132) \text { and } 2020 \\
(n=2317)\end{array}$ & $\begin{array}{c}\text { March-August } 2019 \\
\text { vs. } 2020\end{array}$ & SC: rehabilitation & $\begin{array}{l}\text { Reduction in the global volume of } \\
\text { patients }(44 \%) \text {, first visits }(42 \%) \text {, and } \\
\text { follow-ups }(60.9 \%) \text {, as well as number } \\
\text { of sessions (71.1\%), from lockdown in } \\
\text { March } 2020 \text {, compared to } 2019 \text {. }\end{array}$ \\
\hline Farrugia, 2021 & $\begin{array}{l}\text { Medical records from } \\
\text { Mater Dei Hospital }\end{array}$ & Malta & $\begin{array}{c}\text { Admissions for acute } \\
\text { exacerbations of chronic } \\
\text { obstructive pulmonary } \\
\text { disease in } 2019(n=259) \text { and } \\
2020(n=119)\end{array}$ & $\begin{array}{l}\text { March-May } 2019 \text { vs. } \\
2020\end{array}$ & $\begin{array}{l}\text { SC: respiratory } \\
\text { diseases }\end{array}$ & $\begin{array}{c}\text { Reduction in admissions }(54.2 \%) \text { in } \\
2020 \text { compared to } 2019 \text {. Increase in the } \\
\text { mortality of admitted patients ( } 19.3 \% \\
\text { vs. } 8.4 \%)\end{array}$ \\
\hline Burt, 2021 & $\begin{array}{l}\text { Medical records from } \\
\text { Kawempe National } \\
\text { Referral Hospital }\end{array}$ & Kawempe, Uganda & $\begin{array}{c}\text { Visits to antenatal } \\
(n=14,401), \text { maternal health } \\
(n=33,499), \text { childcare } \\
(n=111,658) \text { and SRH } \\
(n=57,174) \text { services }^{2}\end{array}$ & $\begin{array}{l}\text { July 2019-December } \\
2020\end{array}$ & $\begin{array}{l}\text { SC: sexual and } \\
\text { reproductive health } \\
\text { (SRH) (antenatal, } \\
\text { maternal, pediatrics, } \\
\text { and family planning) }\end{array}$ & $\begin{array}{l}\text { Reduction in antenatal, childcare, and } \\
\text { family planning visits, as well as } \\
\text { hospital deliveries (different values } \\
\text { according to the type of service or } \\
\text { procedure), during the lockdown } \\
\text { months (March-June 2020), compared } \\
\text { to previous months, without clear } \\
\text { subsequent recovery. Increase in } \\
\text { pregnancy complications and fetal and } \\
\text { infant outcomes. }\end{array}$ \\
\hline Das Neves, 2021 & $\begin{array}{l}\text { Medical records from } \\
\text { Marrere Health Center } \\
\text { and monthly official } \\
\text { statistics from the } \\
\text { Ministry of Health }\end{array}$ & $\begin{array}{l}\text { Nampula, } \\
\text { Mozambique }\end{array}$ & $\begin{array}{l}\text { Visits to SRH services } \\
\left(n={\text { aggregated data })^{2}}^{2}\right.\end{array}$ & $\begin{array}{c}\text { March-May } 2019 \\
\text { and } 2020\end{array}$ & $\begin{array}{l}\text { SC: SRH (maternal } \\
\text { and child health) }\end{array}$ & $\begin{array}{l}\text { Reduction in family planning visits } \\
(28 \%) \text {, elective C-sections ( } 28 \%) \text {, first } \\
\text { antenatal visits (26\%), hospital } \\
\text { deliveries ( } 4 \% \text { ) (increase in } \\
\text { out-of-hospital deliveries by } 74 \%) \text {, and } \\
\text { child vaccination (20\%). Only hospital } \\
\text { deliveries drops were statistically } \\
\text { significant. }\end{array}$ \\
\hline
\end{tabular}


Table 1. Cont.

\begin{tabular}{|c|c|c|c|c|c|c|}
\hline $\begin{array}{c}\text { First Author, } \\
\text { Year }\end{array}$ & Data Source & Study Area & $\begin{array}{l}\text { Study Population } \\
\text { and Sample }\end{array}$ & Study Period & Health Service & Main Results \\
\hline $\begin{array}{c}\text { Jensen and } \\
\text { McKerrow, } 2020\end{array}$ & $\begin{array}{c}\text { Medical records from the } \\
\text { KwaZulu-Natal District } \\
\text { Health Information } \\
\text { System }\end{array}$ & $\begin{array}{c}\text { KwaZulu-Natal } \\
\text { district, South Africa }\end{array}$ & $\begin{array}{l}\text { Visits to child health services } \\
\quad \text { (aggregated data })^{2}\end{array}$ & $\begin{array}{c}\text { January 2018-June } \\
2020\end{array}$ & $\begin{array}{l}\text { SC: SRH (maternal } \\
\text { and child health) }\end{array}$ & $\begin{array}{l}\text { Reduction in clinical visits (36\%), } \\
\text { hospital admissions ( } 50 \% \text { ), delivery of } \\
\text { services (from } 6 \% \text { to } 54 \% \text { depending on } \\
\text { the service) in children under } 5 \text { years of } \\
\text { age from March } 2020 \text {. Modest increase } \\
\text { in clinic visits as of May 2020, without } \\
\text { reaching levels of preceding years. } \\
\text { Among delivery of services, } \\
\text { immunization coverage increased } \\
\text { almost to pre-pandemic levels. }\end{array}$ \\
\hline Justman, 2020 & $\begin{array}{l}\text { Medical records from a } \\
\text { tertiary referral center }\end{array}$ & Haifa, Israel & $\begin{array}{c}\text { Pregnant women } \\
\left(n={\text { aggregated data })^{2}}^{2}\right.\end{array}$ & $\begin{array}{l}\text { March-April } \\
\text { 2019-2020 }\end{array}$ & $\begin{array}{l}\text { SC: SRH (maternal } \\
\text { and child health) }\end{array}$ & $\begin{array}{l}\text { Reduction in visits (from } 18.1 \% \text { to } 36.4 \% \\
\text { according to the type of visit), deliveries } \\
\text { ( } 17.1 \% \text { ) and admissions ( } 22.3 \% \text { ) to the } \\
\text { obstetrics and gynecology department } \\
\text { in } 2020 \text { compared to } 2019 \text {. No } \\
\text { significant changes were observed in } \\
\text { the rate of C-sections, although a } \\
\text { greater number of vaginal births during } \\
\text { the outbreak ( } 16.7 \% \text { in } 2020 \text { vs. } 6.8 \% \text { in } \\
2019 \text { ), between the two periods. }\end{array}$ \\
\hline KC, 2020 & $\begin{array}{c}\text { Data collected from a } \\
\text { prospective } \\
\text { observational study in } 9 \\
\text { hospitals (SUSTAIN and } \\
\text { REFINE studies) }\end{array}$ & Nepal & $\begin{array}{l}\text { Pregnant women } \\
\quad(n=21,763)\end{array}$ & $\begin{array}{l}\text { January-March vs. } \\
\text { March-May } 2020\end{array}$ & $\begin{array}{l}\text { SC: SRH (maternal } \\
\text { and child health) }\end{array}$ & $\begin{array}{l}\text { Reduction in hospital deliveries ( } 52.4 \%), \\
\text { especially vaginal births, from } \\
\text { lockdown in March } 2020 \text {. Increase in } \\
\text { preterm births ( } 24.5 \% \text { before lockdown } \\
\text { vs. } 26.2 \% \text { during lockdown), neonatal } \\
\text { deaths (13 per } 1000 \text { livebirths vs. } 40 \text { per } \\
1000 \text { livebirths) and women admitted } \\
\text { with complications during labor ( } 6.7 \% \\
\text { vs. } 8.7 \% \text {, not statistically significant). } \\
\text { AF: lower utilization of SRH services } \\
\text { was less likely among users of } \\
\text { disadvantaged ethnic groups and poor } \\
\text { perceived quality of care. }\end{array}$ \\
\hline
\end{tabular}


Table 1. Cont.

\begin{tabular}{|c|c|c|c|c|c|c|}
\hline $\begin{array}{c}\text { First Author, } \\
\text { Year }\end{array}$ & Data Source & Study Area & $\begin{array}{l}\text { Study Population } \\
\text { and Sample }\end{array}$ & Study Period & Health Service & Main Results \\
\hline Marqués, 2021 & $\begin{array}{l}\text { Medical records from the } \\
\text { Cambridge University } \\
\text { Hospitals NHS } \\
\text { Foundation Trust }\end{array}$ & Cambridge, UK & $\begin{array}{l}\text { Women complaining of a 1st } \\
\text { episode of reduced fetal } \\
\text { movements in } 2019(n=810) \\
\text { and } 2020(n=803)\end{array}$ & $\begin{array}{c}\text { March-April } 2019 \text { vs. } \\
2020\end{array}$ & $\begin{array}{l}\text { SC: SRH (maternal } \\
\text { and child health) }\end{array}$ & $\begin{array}{c}\text { Reduction in 1st visits for reduced fetal } \\
\text { movements (RFM) during 2020, } \\
\text { compared to the same period in } 2019 \\
(18 \% \text { vs. } 22 \%) \text {. } \\
\text { AF: primiparous women were more } \\
\text { likely to attend with RFM. }\end{array}$ \\
\hline $\begin{array}{l}\text { Shakespeare, } \\
2021\end{array}$ & $\begin{array}{l}\text { Medical records from } \\
\text { Mpilo Central Hospital }\end{array}$ & Zimbabwe & $\begin{array}{c}\text { Women who gave birth from } \\
\text { January to June } 2020 \\
(n=\text { aggregated data })^{2}\end{array}$ & $\begin{array}{l}\text { January-March vs. } \\
\text { April-June } 2020\end{array}$ & $\begin{array}{l}\text { SC: SRH (maternal } \\
\text { and child health) }\end{array}$ & $\begin{array}{l}\text { Reduction in visits (5.8\%) for hospital } \\
\text { deliveries from April 2020, compared to } \\
\text { previous months. No significant } \\
\text { changes were observed in maternal or } \\
\text { perinatal mortality and morbidity, nor } \\
\text { in workload, although the number of } \\
\text { deliveries and C-sections fell. Neonatal } \\
\text { deaths increased, not significantly. }\end{array}$ \\
\hline Spurlin, 2020 & $\begin{array}{l}\text { Medical records from the } \\
\text { New York Presbyterian- } \\
\text { Columbia University } \\
\text { Irving Medical Center }\end{array}$ & New York, USA & $\begin{array}{l}\text { Patients who attended } \\
\text { OB-GYN } \\
\text { (obstetrics-gynecology) } \\
\text { services from February to } \\
\text { March } 2020 \text { for emergency } \\
\text { visits }(n=275), \text { GYN } \\
\text { surgeries }(n=212), \text { OB } \\
\text { surgeries }(n=237), \text { and from } \\
\text { March to April 2020 for } \\
\text { emergency visits }(n=79), \\
\text { GYN surgeries }(n=79), \text { OB } \\
\text { surgeries }(n=181)\end{array}$ & $\begin{array}{l}\text { February-March vs. } \\
\text { March-April } 2020\end{array}$ & $\begin{array}{l}\text { SC: SRH (obstetrics } \\
\text { and gynecology) }\end{array}$ & $\begin{array}{l}\text { Reduction in the average weekly } \\
\text { OB-GYN ED consults }(60.3 \%) \text { and GYN } \\
\text { surgeries ( } 79.3 \%) \text {, whereas OB surgeries } \\
\text { remained stable, from March } 2020 \\
\text { compared to the previous period. No } \\
\text { significant differences in the proportion } \\
\text { of OB-GYN ED consults and GYN } \\
\text { surgeries were observed, although the } \\
\text { proportion of OB surgeries increased } \\
\text { significantly (54.6\% before March vs. } \\
79.7 \% \text { from March 2020). }\end{array}$ \\
\hline
\end{tabular}


Table 1. Cont.

\begin{tabular}{|c|c|c|c|c|c|c|}
\hline $\begin{array}{l}\text { First Author, } \\
\text { Year }\end{array}$ & Data Source & Study Area & $\begin{array}{l}\text { Study Population } \\
\text { and Sample }\end{array}$ & Study Period & Health Service & Main Results \\
\hline Chiba, 2021 & $\begin{array}{l}\text { Medical records from the } \\
\text { Medical Center of the } \\
\text { University of Southern } \\
\text { California and Los } \\
\text { Angeles County }\end{array}$ & Los Angeles, USA & $\begin{array}{l}\text { Patients admitted to trauma } \\
\text { in } 2019(n=1143) \text { and } 2020 \\
\qquad(n=1202)\end{array}$ & $\begin{array}{l}\text { March-June } 2019 \text { vs. } \\
\qquad 2020\end{array}$ & SC: traumatology & $\begin{array}{l}\text { Increase in the number admissions } \\
\text { (different values according to the type of } \\
\text { trauma) during the analyzed period of } \\
\text { 2020, compared to } 2019 \text {. Increase in } \\
\text { admissions due to falls ( } 32.4 \% \text { ) (especially } \\
\text { elderly), injuries from the use of weapons } \\
\text { (39.3\%), suicides ( } 38.5 \% \text {, not statistically } \\
\text { significant), and positivity in the use of } \\
\text { substances ( } 52.1 \% \text { in } 2020 \text { vs. } 40.2 \% \text { in } \\
\text { 2019). Reduction in severe trauma ( } 38.7 \% \\
\text { vs. } 46.7 \% \text { ), mortality ( } 4.1 \% \text { vs. } 5.9 \% \text { ), and } \\
\text { ICU admission rates ( } 26.3 \% \text { vs. } 31.5 \% \text { ). } \\
\text { There were non-significant reductions in } \\
\text { admissions due to traffic accidents } \\
\text { (pedestrian or motor). }\end{array}$ \\
\hline
\end{tabular}

Reduction in trauma referrals $(17.1 \%)$ in 2020 compared to 2019.

Medical records from the

Horan, $2021 \quad$ National Neurosurgical Center at Beaumont Hospital
Dublin, Ireland

Referrals to the trauma department in $2019(n=527)$ and $2020(n=437)$
March-May 2019 vs. 2020
SC: traumatology

No significant changes were observed between the profiles most associated with shunts between the two years, although there were changes in the type of diagnosis (fewer brain and spinal injuries and cranial fractures).

AF: referrals were more likely among men, people over 60, alcohol consumers.

Reduction in PC health services (21.4\%) in 2020 compared to 2018 and 2019.

Visits to primary care January 2018-June $(n=875.6 \text { million })^{2}$
2020
PC
Decreases in in-person visits (50.2\%) and

were observed. Evaluations and

medication prescriptions were less 
Table 1. Cont.

\begin{tabular}{|c|c|c|c|c|c|c|}
\hline $\begin{array}{c}\text { First Author, } \\
\text { Year }\end{array}$ & Data Source & Study Area & $\begin{array}{l}\text { Study Population } \\
\text { and Sample }\end{array}$ & Study Period & Health Service & Main Results \\
\hline Sato, 2021 & $\begin{array}{l}\text { Administrative claims } \\
\text { from the DeSC database } \\
\text { (health insurance claims) }\end{array}$ & Japan & $\begin{array}{l}\text { Patients with chronic } \\
\text { neurological diseases }{ }^{2}\end{array}$ & $\begin{array}{c}\text { March-November } \\
2020\end{array}$ & PC & $\begin{array}{l}\text { Reduction in visits for different chronic } \\
\text { neurological diseases (RR 0.9), except } \\
\text { one that increased (migraines, RR 1.15), } \\
\text { from April 2020. Telephone } \\
\text { appointments were most frequently } \\
\text { used in April-May (representing } 5 \% \text { of } \\
\text { the visits), especially in the case of } \\
\text { migraines (OR 2.08). The changes } \\
\text { yielded different effects depending on } \\
\text { the disease. }\end{array}$ \\
\hline Song, 2021 & $\begin{array}{l}\text { Medical records from the } \\
\text { Independence Blue } \\
\text { Cross }\end{array}$ & USA & $\begin{array}{l}\text { Women who had } \\
\text { mammograms from January } \\
2018 \text { to March } 2020 \text { for } \\
\text { screening }(n=213,168) \text { and } \\
\text { diagnosis }(n=55,879) \text {, and } \\
\text { from March to July 2020 for } \\
\text { screening }(n=27,970) \text { and } \\
\text { diagnosis }(n=10,233)\end{array}$ & $\begin{array}{l}\text { January 2018-March } \\
2020 \text { vs. March-July } \\
2020\end{array}$ & Preventive services & $\begin{array}{l}\text { Reduction in the volume of screening } \\
(58 \%) \text { and diagnostic }(38 \%) \\
\text { mammograms from March 2020, } \\
\text { compared to the preceding months and } \\
\text { to the previous years. Increase in } \\
\text { activity from May 2020, remaining } 14 \% \\
\text { below previous months levels. } \\
\text { AF: greater use was associated with } \\
\text { women with a previous diagnosis. }\end{array}$ \\
\hline
\end{tabular}

${ }^{1}$ : General health services include different levels of care or type of service; ${ }^{2}$ : aggregated data and/or no specification of the different periods of analysis; ${ }^{3}$ : studies that did not analyze whether the changes were statistically significant (the rest of articles presented results statistically significant); AF: associated factors; ED: emergency department; ICU: intensive care unit; IRR: incidence rate ratio; OB-GYN: obstetrics-gynecology; OR: odds ratio; PC: primary care; RR: relative risk; SC: secondary care; SRH: sexual and reproductive health. 
Table 2. Quantitative studies on potential access related to the characteristics of the services and the population during the COVID-19 pandemic in 2020.

\begin{tabular}{|c|c|c|c|c|c|c|}
\hline $\begin{array}{l}\text { First Author, } \\
\text { Year }\end{array}$ & $\begin{array}{l}\text { Data Collection } \\
\text { Method }\end{array}$ & Study Area & $\begin{array}{c}\text { Study Population and } \\
\text { Sample }\end{array}$ & Study Period & Health Service & Main Results \\
\hline $\begin{array}{c}\text { Kahraman et al., } \\
2021\end{array}$ & Online survey & Turkey & $\begin{array}{l}\text { Patients with lysosomal } \\
\text { storage disease in enzyme } \\
\text { replacement therapy }(n=75)\end{array}$ & July-October 2020 & SC: endocrinology & $\begin{array}{l}\text { Characteristics of the services: lack of } \\
\text { resources (hospital beds) } \\
\text { Characteristics of the population: fear } \\
\text { of contagion, difficulties in obtaining } \\
\text { medication, transport difficulties }\end{array}$ \\
\hline $\begin{array}{l}\text { Nicholson et al., } \\
2020\end{array}$ & Online survey & Ireland & $\begin{array}{l}\text { Parents of children under } 16 \\
\qquad(n=1044)\end{array}$ & June 2020 & SC: pediatrics & $\begin{array}{l}\text { Characteristics of the population: fear } \\
\text { of contagion, perception of overuse of } \\
\text { services or lack of need, fear of being } \\
\text { judged for seeking care, poor } \\
\text { understanding of government } \\
\text { messages, concern regarding travel } \\
\text { (avoiding public transport). }\end{array}$ \\
\hline $\begin{array}{l}\text { Benjamen et al., } \\
2021\end{array}$ & $\begin{array}{l}\text { Online survey ( } n=77 \text {, of } \\
\text { which } 11 \text { were } \\
\text { interviewed in depth) }\end{array}$ & Ottawa, Canada & $\begin{array}{l}\text { Doctors with experience } \\
\text { caring for refugee } \\
\text { populations }(n=77)\end{array}$ & May-August 2020 & SC: psychiatry & $\begin{array}{l}\text { Characteristics of the services: limited } \\
\text { availability of providers and } \\
\text { community resources, slight increase in } \\
\text { the offer of virtual care psychotherapy. } \\
\text { Characteristics of the population: fear } \\
\text { of contagion, perceived lack of services, } \\
\text { technological barriers }\end{array}$ \\
\hline Halley et al., 2021 & Online surve & USA & $\begin{array}{l}\text { Relatives }(n=139) \text { and } \\
\text { patients affected by } \\
\text { undiagnosed rare diseases } \\
\qquad(n=275)\end{array}$ & April-June 2020 & $\begin{array}{l}\text { SC: undiagnosed rare } \\
\text { diseases care }\end{array}$ & $\begin{array}{l}\text { Characteristics of the services: barriers } \\
\text { to access essential services (difficulties } \\
\text { in contacting services, procedures } \\
\text { re-scheduled, lack of medical supplies, } \\
\text { insufficient telemedicine care offered), } \\
\text { restrictions on companions. } \\
\text { Characteristics of the population: fear } \\
\text { of COVID-19 contagion; impact on } \\
\text { physical and mental health (stress due } \\
\text { to not being able to receive treatment or } \\
\text { as an aggravating factor of the disease). }\end{array}$ \\
\hline
\end{tabular}


Table 2. Cont.

\begin{tabular}{|c|c|c|c|c|c|c|}
\hline $\begin{array}{c}\text { First Author, } \\
\text { Year }\end{array}$ & $\begin{array}{l}\text { Data Collection } \\
\text { Method }\end{array}$ & Study Area & $\begin{array}{c}\text { Study Population and } \\
\text { Sample }\end{array}$ & Study Period & Health Service & Main Results \\
\hline $\begin{array}{l}\text { Adelekan et al., } \\
2021\end{array}$ & $\begin{array}{l}\text { Semi-structured } \\
\text { interviewer- } \\
\text { administered } \\
\text { questionnaire }\end{array}$ & Nigeria & $\begin{array}{l}\text { Head nurses and midwives } \\
\text { in primary health centers } \\
\qquad(n=307)\end{array}$ & $\begin{array}{c}\text { March-September } \\
2020\end{array}$ & $\begin{array}{l}\text { SC: SRH (maternal } \\
\text { and child health) }\end{array}$ & $\begin{array}{l}\text { Characteristics of the services: } \\
\text { difficulties regarding out-of-stock drugs } \\
\text { and contraceptives. } \\
\text { Characteristics of the population: } \\
\text { economic difficulties (not being able to } \\
\text { afford cost of transportation). }\end{array}$ \\
\hline $\begin{array}{l}\text { Karavadra et al., } \\
2020\end{array}$ & Online survey & UK & $\begin{array}{l}\text { Women who were pregnant } \\
\text { or gave birth during the } \\
\text { COVID-19 pandemic } \\
\qquad(n=1451)\end{array}$ & May 2020 & $\begin{array}{l}\text { SC: SRH (maternal } \\
\text { and child health) }\end{array}$ & $\begin{array}{l}\text { Characteristics of the services: reduced } \\
\text { frequency of scans, redistribution of } \\
\text { services in different "zoned areas" } \\
\text { based on "COVID wards" and } \\
\text { "non-COVID" wards, lack of } \\
\text { information, ban on presence of partner. } \\
\text { Characteristics of the population: fear } \\
\text { of contagion, perception of "impersonal } \\
\text { care" from virtual consultations. }\end{array}$ \\
\hline Khan et al., 2021 & Online survey & $\begin{array}{l}64 \text { middle- and } \\
\text { low-income } \\
\text { countries of Africa, } \\
\text { Asia, and Latin } \\
\text { America }\end{array}$ & $\begin{array}{l}\text { Health professionals from } \\
\text { tuberculosis treatment } \\
(n=567) \text { and HIV }(n=346) \\
\text { services }\end{array}$ & May-August 2020 & $\begin{array}{c}\text { SC: tuberculosis and } \\
\text { HIV care }\end{array}$ & $\begin{array}{l}\text { Characteristics of the services: lack of } \\
\text { material and medical supplies, } \\
\text { difficulties in obtaining medical } \\
\text { treatment, lack of alternatives for } \\
\text { non-face-to-face care (e.g., } \\
\text { telemedicine), postponement of visits } \\
\text { for diagnoses and treatments. } \\
\text { Characteristics of the population: fear } \\
\text { of contagion, stigma, difficulties in } \\
\text { accessing health services (alterations in } \\
\text { transportation, restrictions), worsening } \\
\text { economic situation. }\end{array}$ \\
\hline $\begin{array}{l}\text { García-Rojo et al., } \\
2021\end{array}$ & $\begin{array}{c}\text { Medical records } \\
\text { (Hospital } 12 \text { de Octubre) }\end{array}$ & Spain & $\begin{array}{l}\text { Patients on the waiting list } \\
\text { for urological surgery } \\
\qquad(n=350)\end{array}$ & May 2020 & SC: urology & $\begin{array}{l}\text { Characteristics of the services: } \\
\text { increased waiting times for urological } \\
\text { surgeries (designated as elective). }\end{array}$ \\
\hline
\end{tabular}

SC: secondary care; SRH: sexual and reproductive health. 
Table 3. Qualitative studies on potential access related to the characteristics of the services and the population during the COVID-19 pandemic in 2020.

\begin{tabular}{|c|c|c|c|c|c|c|}
\hline $\begin{array}{c}\text { First Author, } \\
\text { Year }\end{array}$ & $\begin{array}{l}\text { Data Collection } \\
\text { Method }\end{array}$ & Study Area & $\begin{array}{c}\text { Study Population and } \\
\text { Sample }\end{array}$ & Study Period & Health Service & Main Results \\
\hline $\begin{array}{c}\text { Zambrano et al., } \\
2021\end{array}$ & $\begin{array}{l}\text { Online semi-structured } \\
\text { interviews and life } \\
\text { histories }\end{array}$ & Colombia and Peru & $\begin{array}{l}\text { Venezuelan migrant } \\
\text { populations living in large } \\
\text { cities in Colombia }(n=96) \\
\text { and Peru }(n=34)\end{array}$ & July-September 2020 & General & $\begin{array}{l}\text { Characteristics of the services: access to } \\
\text { health services linked to legal } \\
\text { immigration status. } \\
\text { Characteristics of the population: } \\
\text { severe economic difficulties, perceived } \\
\text { discrimination of healthcare services on } \\
\text { the basis of nationality }\end{array}$ \\
\hline $\begin{array}{c}\text { Gichuna et al., } \\
2020\end{array}$ & $\begin{array}{c}\text { Semi-structured } \\
\text { interviews via mobile } \\
\text { phone (phone call or } \\
\text { videocall) }\end{array}$ & $\begin{array}{c}\text { Kariobangi, } \\
\text { Roysambu, and } \\
\text { Jogoo Road areas } \\
\text { (Nairobi, Kenya) }\end{array}$ & $\begin{array}{l}\text { Sex workers from the study } \\
\text { areas }(n=117) \text {, and health } \\
\text { professionals from the Bar } \\
\text { Hostess Empowerment and } \\
\text { Support Program Centers } \\
\qquad(n=15)\end{array}$ & April-May 2020 & $\begin{array}{l}\text { SC: SRH (family } \\
\text { planning) and HIV } \\
\text { care }\end{array}$ & $\begin{array}{l}\text { Characteristics of the services: reduced } \\
\text { activity, lack of medical supplies } \\
\text { Characteristics of the population: } \\
\text { economic difficulties, stigma }\end{array}$ \\
\hline $\begin{array}{l}\text { Hailemariam } \\
\text { et al., } 2021\end{array}$ & $\begin{array}{l}\text { Online focal groups (6) } \\
\text { and semi-structured } \\
\text { interviews (9) }\end{array}$ & Kebeles, Ethiopia & $\begin{array}{l}\text { Pregnant women who did } \\
\text { not attend SHR services and } \\
\text { health workers }\end{array}$ & $\begin{array}{l}\text { September- } \\
\text { November } \\
2020\end{array}$ & $\begin{array}{l}\text { SC: SRH (maternal } \\
\text { and child health) }\end{array}$ & $\begin{array}{l}\text { Characteristics of the population: } \\
\text { perceived low quality of services, fear } \\
\text { of contagion, stigma, playing down care } \\
\text { needs, refusal to attend antenatal } \\
\text { services. }\end{array}$ \\
\hline $\begin{array}{l}\text { Mizrak Sahin, } \\
\text { and Nur Kabakci, } \\
2020\end{array}$ & $\begin{array}{c}\text { Semi-structured } \\
\text { interviews by phone }\end{array}$ & Turkey & Pregnant women & $\begin{array}{l}\text { During 2020, months } \\
\text { not specified }\end{array}$ & $\begin{array}{l}\text { SC: SRH (maternal } \\
\text { and child health) }\end{array}$ & $\begin{array}{l}\text { Characteristics of the services: elective } \\
\text { visits were cancelled or postponed, } \\
\text { difficulties in getting first visits. } \\
\text { Characteristics of the population: fear } \\
\text { of contagion, difficulties in contacting } \\
\text { services for first visits. }\end{array}$ \\
\hline
\end{tabular}


Table 3. Cont.

\begin{tabular}{|c|c|c|c|c|c|c|}
\hline $\begin{array}{c}\text { First Author, } \\
\text { Year }\end{array}$ & $\begin{array}{l}\text { Data Collection } \\
\text { Method }\end{array}$ & Study Area & $\begin{array}{c}\text { Study Population and } \\
\text { Sample }\end{array}$ & Study Period & Health Service & Main Results \\
\hline $\begin{array}{l}\text { Dos Santos et al., } \\
2021\end{array}$ & $\begin{array}{l}7 \text { semi-structured } \\
\text { interviews by phone }\end{array}$ & Ribeirão Preto, Brazil & $\begin{array}{l}\text { Patients over } 18 \text { years old } \\
\text { undergoing treatment for } \\
\text { tuberculosis }\end{array}$ & June-August 2020 & SC: tuberculosis care & $\begin{array}{l}\text { Characteristics of the population: } \\
\text { economic difficulties, fear of contagion }\end{array}$ \\
\hline $\begin{array}{l}\text { Ahmed et al., } \\
2020\end{array}$ & $\begin{array}{l}\text { Workshops and } \\
\text { in-person meetings in } \\
\text { three pre-pandemic } \\
\text { phases (semi-structured } \\
\text { interviews, group and } \\
\text { individual meetings), } \\
\text { and a fourth phase via } \\
\text { mobile phone }\end{array}$ & $\begin{array}{l}\text { Bangladesh, Kenya, } \\
\text { Nigeria, Pakistan }\end{array}$ & $\begin{array}{l}\text { Health professionals } \\
\text { (medical doctors, nurses, } \\
\text { community health workers } \\
\text { and assistants, pharmacists, } \\
\text { and patent medicine } \\
\text { vendors), pregnant women } \\
\text { and women with children, } \\
\text { health service managers }\end{array}$ & $\begin{array}{l}\text { March 2018-May } \\
2020\end{array}$ & PC & $\begin{array}{l}\text { Characteristics of the services: worse } \\
\text { access to services that were difficult to } \\
\text { access before the pandemic (mental } \\
\text { health, gender-based violence services), } \\
\text { and preventive services, increase in cost } \\
\text { of healthcare, lack of drugs and medical } \\
\text { supplies. } \\
\text { Characteristics of the population: fear } \\
\text { of contagion, economic difficulties. }\end{array}$ \\
\hline $\begin{array}{l}\text { Danhieux et al., } \\
2020\end{array}$ & $\begin{array}{l}\text { Online semi-structured } \\
\text { interviews }\end{array}$ & Belgium & $\begin{array}{c}\text { General practitioners, } \\
\text { nurses, and dieticians } \\
(n=21) \text { in primary care who } \\
\text { work individually, } \\
\text { monodisciplinary or in } \\
\text { multidisciplinary groups }\end{array}$ & April-June 2020 & PC & $\begin{array}{l}\text { Characteristics of the services: limited } \\
\text { resources to treat, identify, and contact } \\
\text { non-COVID-19 patients because of the } \\
\text { redistribution of resources, especially } \\
\text { among high-risk and vulnerable } \\
\text { patients. }\end{array}$ \\
\hline
\end{tabular}

PC: primary care; SC: secondary care; SRH: sexual and reproductive health. 
With regard to the type of service, of the studies on realized access, 5 focused on health services in general [46-50]; 12 on emergencies [51-62] (of which 5 were related to pediatric emergencies [56-58,60,61]); 15 on secondary care (SC) (outpatient visits, hospital admissions, etc., for nephrology [63], oncology [64,65], pediatrics [66], psychiatry [67,68], rehabilitation [69], respiratory diseases [70], sexual and reproductive health (SRH) [71, 73-75], and traumatology [78,79]); two on primary care (PC) [80,81]; one on preventive services [82]. Of the studies on potential access, 1 focused on health services in general [91], 13 on SC (endocrinology [83], rare diseases [86], pediatrics [84], psychiatry [85], SRH [87,88, 93-95], tuberculosis [89,96] and urology [90]); and 2 on PC [92,97]. The study that analyzed changes in both realized and potential access focused on SC relating to SRH [98].

In terms of geographical area, 19 studies were conducted in European countries [47, $51,53,55,57,62,64,67-70,75,79,83,84,88,90,92,95], 9$ in North American countries [49,58,59, $77,78,80,82,85,86], 9$ in Sub-Saharan Africa [46,48,71,72,76,87,93,94,98], 3 in Latin America $[60,91,96], 5$ in the East Asia-Pacific region $[50,56,61,66,81], 3$ in South Asia $[63,65,74]$, 2 in the North Africa-Middle East region [52], and, lastly, 3 studies covered various regions $[54,89,97]$.

With regard to the period of analysis, 38 of the selected studies were conducted over the first months of the pandemic (February to June 2020) [46-55,57-60,62,65-70,72$80,82,84,86,88,90,92,93,98] ; 4$ during the second stage of the pandemic (June to September 2020) $[85,89,91,96] ; 1$ at a later stage (September to November 2020) [94]; finally, 8 analyzed the whole period (February to December 2020) $[56,61,63,64,71,81,83,87]$. No studies were found that analyzed periods after December 2020. All studies that analyzed realized access presented their results in comparison with a previous period: 32 of the first-stage studies compared the changes to pre-pandemic periods of reference [46-55,57-60,62,65$70,72-80,82,98]$, as did 6 of those that analyzed the whole period $[56,61,63,64,71,83]$. One study did not specify the exact period of 2020 analyzed [95].

Below is a summary of results found regarding changes in realized access and potential access, following the Aday and Andersen theoretical framework [39,40].

\subsection{Changes in the Utilization of Health Services and Influencing Factors}

Of the 38 studies that analyzed changes in realized access [46-82,98], 33 indicated a statistically significant descent in the use of services and only one reported an increase [78], and 4 descriptive studies also found a reduction in the use of services $[47,61,63,65]$ (Table 1). After the first few months of the pandemic, some studies described an increase in the utilization, without reaching levels previous to the COVID-19 pandemic [48,61,63,71,72,82]. However, among the studies that extended their analysis to the end of 2020, there are reports of new drops in the utilization of services, coinciding with the onset of new waves of COVID-19 [61,63,71].

By type of service analyzed, studies focusing on the health services in general [46,47, 49,50 ] described an overall drop in use, which varied in terms of magnitude. Among those that analyzed changes in emergency care [51-62,66,77], it was reported that, although the volume of consultations fell, there was an increase in the number of cases with additional complications $[53,58,66,74,77]$ and cases requiring admission to hospital $[51,55,57,59,60,67$, 70]. Likewise, the studies on changes in SC services also reported a reduction in the use of services, while in some cases detecting an increase in the proportion of visits or hospital admissions in concrete healthcare areas (e.g., severe mental health cases [47] or trauma injuries $[56,58,78])$. With respect to PC, both studies described a drop in the number of in-person visits and an increase in remote care consultations (via various mechanisms, such as consultation by telephone or videocall) [66,80]. Lastly, the study that analyzed changes in the use of preventive services [82], along with others that also assessed procedures classified as elective $[49,53,63,64,77]$, reported a drop in use but with less pronounced changes in urgent cases [57,62,82]. 
In the studies that analyzed influencing factors in the use of services in the context of the pandemic, the probability of lower utilization levels was associated with different factors. With regard to predisposing characteristics of the population, women [56,79] and ethnic minorities $[49,74]$ were less likely to access health services, with inconsistent results regarding the elderly [52,79]. As for individual enabling characteristics, the likelihood of a lower use of services was associated with people with a low income and limited healthcare coverage [49,74], and for those enabling characteristics related to the type of area, a higher incidence of COVID-19 [50]. In terms of need, the probability of using health services was lower among patients who lacked a previous diagnosis [82], had less severe conditions (without complications or adverse outcomes) [67], and did not require hospitalization $[52,57,67]$.

\subsection{Potential Access: Barriers Related to Characteristics of the Services and Population}

The 16 studies that analyzed potential access [83-98] described changes in the factors that influenced access before the COVID-19 pandemic and the emergence of new barriers, in terms of both the characteristics of the services and those of the population (Tables 2 and 3).

Twelve studies described changes related to characteristics of the services $[83,85-$ $90,92,93,95,97,98]$. The most significant of these was a reported decrease in available resources, both in terms of materials and medical supplies [83,86,89,93,97], and of staff to care for non-COVID patients $[83,85,88,89,92,95]$, which in certain cases forced some health centers to close $[93,97]$. Two studies pointed out increases in waiting times $[90,98]$ and one a rise in the cost of services [97].

Fourteen studies identified barriers related to population characteristics [83-89,91,9398]. Among the predisposing factors identified, fear of contagion was one of the main reasons for not going to the health services $[83-86,88,89,94-98]$, as well as the stigma that receiving a COVID-19 diagnosis would create [89,94,97]. Other factors found included people misinterpreting government recommendations to avoid going to the health services [84], perceiving that the services were of poor quality [94], or believing they would have difficulties in gaining access $[85,86,91,93]$ during the pandemic. With respect to enabling factors, authors highlighted the worsening socioeconomic situation of the population $[87,89,91,93,94,96,97]$, a lack of support networks [93,94], and an increase in technological barriers $[85,88]$ as some of the main factors that hindered access to the health services. Lastly, they also underlined tendencies to play down the risk of health complications and the perceived need for medical attention $[94,98]$ as barriers that had the effect of reducing the use of services and delaying the decision to seek care during the pandemic.

\section{Discussion}

The impact of the COVID-19 pandemic has been felt worldwide in many different spheres of society, but especially in access to health services for unrelated conditions. There is now a pressing need to evaluate the changes that have arisen in this regard, and their implications for equity of access and the resilience of national health systems to future pandemics. This is, to the best of our knowledge, the first scoping review to offer a general overview of the subject, taking in the current evidence and highlighting the areas that will require further research in future studies.

Most of the studies included in the analysis describe a lower level of health services' utilization and changes in potential access, as preexisting barriers have intensified and new ones have arisen. However, while investigations into the impact of the COVID-19 pandemic are still ongoing, the results of this review show that the studies conducted to date are limited in terms of scope and methodology, and that they are mainly centered on analyzing the impact on the use of services for specific diseases or population groups during the first stages of the pandemic, with a particular focus on secondary care.

Studies on the use of health services in general are very scarce, as are those on access to primary care, which in many countries has been the most overwhelmed care level 
due to having to take on more pandemic-related care duties (vaccination, case tracking, etc.). Likewise, there is a considerable lack of evidence so far on how changes have taken place over the course of the different waves of COVID-19, and according to geographical context. Although some studies with longer timeframes-to the end of 2020-have already described new drops in health services' activity following brief periods of recovery [61,63, 71], further evidence is required to confirm this trend. Moreover, we have yet to look into how the pandemic has affected unmet care needs, as some studies showed that one of the most commonly reported impact was that patients delayed seeking care due to factors such as fear of contagion, disinformation, etc. [83-86,88,89,94,95,97,98].

It is important to bear in mind that access to care involves multiple interdependent factors and numerous actors. However, the results of this review show that, so far, there are almost no published studies with a wide scope using mixed methods, and that the qualitative studies available to date are still limited in both number and perspective. In regard to the latter, few studies include, in addition to that of users, other viewpoints such as that of the health professionals or managers involved in the process of taking measures or adopting practices that influenced access to care. Furthermore, the population groups selected for study were generally sufferers of a specific condition or of vulnerable status. The number of qualitative studies is probably limited due to the complexity of their development in the pandemic context, in terms of time, resources, and restrictions imposed by the mitigation measures. Approaches that combine multiple sources of evidence and different perspectives are needed to shed more light on the factors and actors that have influenced access.

With regard to our main findings on the reduction in the use of services, this may be related to health systems prioritizing their response to the public health emergency, which differed according to context $[4,25,99,100]$. Initial measures were generally centered on containing the spread of COVID-19 and providing the health services with the resources needed to meet the soaring demand for medical attention, which led to the classification of some services and procedures as non-essential, and a consequent reduction in the resources allocated to cover those health needs $[3,4,7,8]$. There is a lack of evidence on how the measures were modified and adapted according to context as the pandemic progressed, and the patterns of utilization that they generated, although some studies have already revealed changes in use with recoveries and relapses, in the more advanced stages of the pandemic $[61,63,71]$.

Going into more detail, the reductions in access to services described appear to have brought with them an increase in medical complications and emergencies, especially in elective procedures $[48,49,52,53,58,59,67,71,74,77,101]$, and/or care delays (time passed between onset of symptoms and intervention) [53,98], although it is generally not specified whether the delays were due to patients putting off seeking medical attention or rather to an increase in barriers to access the services. Some studies also observed higher mortality rates [52,70,74,76] and burden of disease [62]. However, while emergency care was one of the greatest causes for concern [51-62], according to our results the downturns recorded for this type of service appear to be less pronounced or of lower impact than those reported in other fields.

In this regard, some studies highlight the difficulties involved in maintaining normal levels of activity in certain services, even in some classed as essential, such as maternal health, oncology, or mental health $[71,76,85,89,93,94,97,98]$. The impact appears to have been felt worldwide but especially in middle- and low-income countries, a point that has also been stressed in various opinion articles [101-107]. Differences between health systems, and between geographical contexts, may both have acted as determining factors in the changes seen. Sexual and reproductive health services analyzed in African and South Asian countries, for example, have seen a significant downturn in access, not only to maternal and child health services but also other non-essential areas of health care (family planning, sexually transmitted diseases, etc.) $[71,74,76,93,98]$, despite the warnings given in various reports and opinion articles based on previous epidemic experience $[2,26,101,108]$ 
of the risk this poses in terms of burden of disease and mortality [2,25,26,103-106,109-114]. Another example can be found in the lack of care for patients at risk of a cancer diagnosis due to delays in screening and diagnostic programs caused by certain procedures being classified as elective $[64,65,82]$, which could also lead to an increase in the burden of disease and mortality due to the late detection of new cancer cases, as several studies pointed out [35,115-118]. As regards mental health, various studies mention anxiety and other disorders related to fear of contagion and the uncertainty that the pandemic generated in its first few months $[35,55,77,83-86,88,91,94-96]$, as well as difficulties in access to mental health services $[68,85,97]$ and an increase in acute cases of severe disorders [67]. These issues may have caused the burden of disease to increase, which could influence service utilization patterns in the years to follow, an aspect that was observed previously with the SARS epidemic in 2003 [119] and that should be taken into consideration in future studies on the impact of COVID-19.

The few studies that analyze the influencing factors on the lower utilization of services mainly highlight a greater downturn in use among low-income users, those with limited healthcare coverage, and ethnic minorities [49,74], as well as the female population [56,79], all of which signals greater inequalities with regard to more vulnerable populations.

As regards the changes in potential access detected in this review, the results indicate both the exacerbation of existing barriers, related above all to structural difficulties and situations of vulnerability, and the creation of new ones. In terms of existing barriers accentuated by the pandemic, some studies reported a shortage of resources in the services to meet all the incoming healthcare requests $[83,85,86,88,89,92,93,95,97,98]$, which varied according to service and geographical context. One of the most serious problems was the lack of or alterations to the distribution of materials and medical supplies in lowincome countries $[83,87,89,93,94,97]$, an aspect corroborated in other publications, both reports and opinion articles [4,34,104,120-122]. The lack of materials and medical supplies may have contributed to increasing negative perceptions of the quality of the health services, especially in disadvantaged settings or situations with structural difficulties, another barrier to access found by some studies $[93,94,97]$. Lastly, several studies in this review $[83,85,87,89,91,93,97]$ and some reports $[12,123]$ focusing on vulnerable population groups (such as migrants or refugees, sex workers, people at a severe socioeconomic disadvantage) highlight the worsening economic situation and the intensification of other barriers (legal, information-related, or discriminatory), as has also occurred in previous epidemics [19]. All this points to situations in which the ability of these groups to access the health services and receive care may have diminished yet further.

In addition, new barriers may have been created as a result of adopting alternatives to face-to-face visits (online consultation, telephone, video call, telemedicine, etc.) and changes in attitudes and beliefs developed as a result of the pandemic. In this regard, the use of online consultation has grown as a way to mitigate difficulties in access [4], but not in the same way across all contexts [3,124]. Several articles included in the review described inequalities in access, reporting access problems related to digital literacy (lack of understanding of digital devices) or a lack of material resources (Internet connection, mobile devices) $[49,85,89]$, a point also highlighted in other publications $[125,126]$, alongside the perception that the care received in virtual consultation is impersonal [88]. These results are in keeping with numerous publications that have focused on the changes from face-to-face consultations to remote care and user satisfaction with the latter [29,80,127-136]. However, most studies are centered mainly on high-income countries, thus, further evidence in different contexts is required on the impact of remote care on access to the health services.

Likewise, one of the individual characteristics that has been most influential in terms of new barriers created by the pandemic is fear of contagion [83-86,88,89,94,95,97], an aspect that has been discussed in many publications, including opinion articles [113,137-142], and also played a highly significant role in previous epidemics as a factor causing problems or delays in seeking medical care $[2,21,24,26,72,76,101,108,143,144]$. Other factors reported include the stigma associated with seeking care $[84,89,93,94,97]$, also described in other 
publications $[109,145]$, and users playing down the need for medical treatment $[84,94,98]$ and perceiving a lack of response on the part of the health services [85,88].

While it is true that various studies have identified both new barriers and the exacerbation of existing ones, the behavior of individuals in this type of public health emergency requires more in-depth analysis in order to steer the design of interventions to help counter these barriers, such as public health information campaigns or specific measures for vulnerable populations.

On a final note, this review has several limitations. In the first place the nature of the studies covered varies greatly, in terms of methodology (ways of measuring use of services, information sources, sample size, etc.), and of geographical areas and health systems analyzed; thus, it is not possible to draw comparisons between them. Secondly, articles that analyzed access to services due to COVID-19 in addition to other illnesses were excluded from the study. This decision was made in order to rule out bias towards activity and resources destined to the treatment of other diseases. Third, no studies focusing on the impact of the pandemic control measures on access to health services were found, probably due to the limited terms used in our search to capture this area. Moreover, it is also possibly due to the difficulties involved in distinguishing the impact of the measures from other effects of the pandemic. Finally, some articles may not have been considered on being published in other languages (Chinese, Arabic, etc.), so this analysis may have excluded relevant information and failed to consider certain contexts. In spite of these limitations, this is the first study to address changes in access from a global perspective, with a view to shedding light on gaps in knowledge that will require further research in the future.

\section{Conclusions}

This review analyzed studies that reported changes in health services' utilization, and the factors that influenced the use of services for non-COVID-19 conditions, during the COVID-19 pandemic. Results vary according to the context analyzed, although, in general terms, they reflect the same trend, describing a general reduction in the use of health services, the exacerbation of preexisting barriers, and the emergence of new ones. This scoping review has shown that most studies conducted to date are limited in terms of scope and methodology and are centered mainly on the impact on specific conditions or population groups during the early stages of the pandemic, focusing mostly on secondary care. Furthermore, a significant gap in knowledge was detected on whether the services have recovered to pre-pandemic levels of care use and, if not, in which areas and for what reasons. Future studies should go into greater depth on the pandemic-related changes that have influenced access to health services (e.g., fear and socioeconomic difficulties), according to context and over the course of the different stages of the pandemic. In any case, as an ongoing phenomenon, the real impact of the COVID-19 pandemic is yet to be determined.

Author Contributions: G.P. designed the research protocol, under the supervision of A.O.-A., I.V. and M.-L.V. In collaboration with her three supervisors, she carried out the bibliographic search and wrote the first version of the manuscript. They all participated in decisions on which studies to include in the analysis, and in the interpretation of results and the writing of the final version of the manuscript. All authors have read and agreed to the published version of the manuscript.

Funding: This research received no external funding. G.P. received the CSC grant to conduct this study as her thesis for the Master in Public Health (Universitat Pompeu Fabra).

Institutional Review Board Statement: Not applicable.

Informed Consent Statement: Not applicable.

Conflicts of Interest: The authors declare no conflict of interest. 


\section{Appendix A}

\section{Search Strategy in Medline}

1. Access to health care services: $(((()((()(((($ health services accessibility[MeSH Terms]) OR (health services accessibility)) OR (accessing)) OR (accessibility)) OR (access)) OR (utilization)) OR (delivery of health care)) OR (healthcare services)) OR (Health Services Needs and Demand[MeSH Terms])) OR (Healthcare Disparities[MeSH Terms])) OR (Needs Assessment[MeSH Terms])) OR (Health Policy[MeSH Terms])) OR (Equipment and Supplies Utilization[MeSH Terms])) OR (Facilities and Services Utilization[MeSH Terms]))

2. AND

3. COVID-19: $((((((($ coronavirus disease) OR (COVID-19)) OR (coronavirus)) OR (SARSCoV-2)) OR (Coronavirus Infections[MeSH Terms])) OR (COVID-19[MeSH Terms])) OR (SARS-CoV-2[MeSH Terms])) OR (coronavirus[MeSH Terms]))

4. Filters: December 2019-March 2021/March-September 2021.

\section{References}

1. Organización Mundial de la Salud Cronología de la Respuesta de la OMS a la COVID-19. Available online: https:/ /www.who. int/es/news/item/29-06-2020-covidtimeline (accessed on 6 November 2020).

2. Hussein, J. COVID-19: What implications for sexual and reproductive health and rights globally? Sex. Reprod. Health Matters 2020, 28, 1746065. [CrossRef] [PubMed]

3. Linn, L.; Oliel, S.; Baldwin, A. La COVID-19 afectó el Funcionamiento de los Servicios de Salud para Enfermedades no Transmisibles en las Américas-OPS/OMS I Organización Panamericana de la Salud. Available online: https://www.paho.org/ es/noticias/17-6-2020-covid-19-afecto-funcionamiento-servicios-salud-para-enfermedades-no (accessed on 12 October 2020).

4. World Health Organization. Pulse Survey on Continuity of Essential Health Services during the COVID-19 Pandemic: Interim Report, 27 August 2020; World Health Organization: Geneva, Switzerland, 2020.

5. World Health Organization. Second Round of the National Pulse Survey on Continuity of Essential Health Services during the COVID-19 Pandemic: January-March 2021; World Health Organization: Geneva, Switzerland, 2021.

6. Global Health Cluster COVID-19 Task Team. Essential Health Services: A guidance Note. How to Prioritize and Plan Essential Health Services during COVID-19 Response in Humanitarian Settings; Health Cluster: Geneva, Switzerland, 2020.

7. Ma, X.; Vervoort, D.; Reddy, C.L.; Park, K.B.; Makasa, E. Emergency and essential surgical healthcare services during COVID-19 in low- and middle-income countries: A perspective. Int. J. Surg. 2020, 79, 43-46. [CrossRef]

8. Teslya, A.; Pham, T.M.; Godijk, N.G.; Kretzschmar, M.E.; Bootsma, M.C.J.J.; Rozhnova, G. Impact of self-imposed prevention measures and short-term government-imposed social distancing on mitigating and delaying a COVID-19 epidemic: A modelling study. PLoS Med. 2020, 17, e1003499. [CrossRef]

9. Porthé, V.; Vargas, I.; Sanz-Barbero, B.; Plaza-Espuña, I.; Bosch, L.; Vázquez, M.L. Changes in access to health care for immigrants in Catalonia during the economic crisis: Opinions of health professionals and immigrant users. Health Policy 2016, 120, 1293-1303. [CrossRef] [PubMed]

10. Krishnan, L.; Ogunwole, S.M.; Cooper, L.A. Historical Insights on Coronavirus Disease 2019 (COVID-19), the 1918 Influenza Pandemic, and Racial Disparities: Illuminating a Path Forward. Ann. Intern. Med. 2020, 173, 474-481. [CrossRef] [PubMed]

11. Dasgupta, J.; Schaaf, M.; Contractor, S.Q.; Banda, A.; Viana, M.; Kashyntseva, O.; Ruano, A.L. Axes of alienation: Applying an intersectional lens on the social contract during the pandemic response to protect sexual and reproductive rights and health. Int. J. Equity Health 2020, 19, 130. [CrossRef]

12. Skogberg, N.; Koponen, P.; Lilja, E.; Austero, S.; Prinkey, T.; Castaneda, A.E. Impact of COVID-19 on the Health and Wellbeing of Persons Who Migrated to Finland: The MigCOVID Survey 2020-2021; Finnish Institute of Health and Welfare's: Helsinki, Finland, 2021.

13. Frohlich, K.L.; Potvin, L. Transcending the known in public health practice: The inequality paradox: The population approach and vulnerable populations. Am. J. Public Health 2008, 98, 216-221. [CrossRef]

14. Suhrcke, M.; Stuckler, D.; Suk, J.E.; Desai, M.; Senek, M.; McKee, M.; Tsolova, S.; Basu, S.; Abubakar, I.; Hunter, P.; et al. The impact of economic crises on communicable disease transmission and control: A systematic review of the evidence. PLoS ONE 2011, 6, e20724. [CrossRef] [PubMed]

15. Nagai, M.; Oikawa, M.; Tamura, T.; Egami, Y.; Fujita, N. Can we apply lessons learned from Ebola experience in West Africa for COVID-19 in lower income countries? Glob. Health Med. 2020, 2, 140-141. [CrossRef] [PubMed]

16. Nuzzo, J.B.; Meyer, D.; Snyder, M.; Ravi, S.J.; Lapascu, A.; Souleles, J.; Andrada, C.I.; Bishai, D. What makes health systems resilient against infectious disease outbreaks and natural hazards? Results from a scoping review. BMC Public Health 2019, 19, 1310. [CrossRef] 
17. Phillips, D.E.; Bhutta, Z.A.; Binagwaho, A.; Boerma, T.; Freeman, M.C.; Hirschhorn, L.R.; Panjabi, R. Learning from Exemplars in Global Health: A road map for mitigating indirect effects of COVID-19 on maternal and child health. BMJ Glob. Health 2020, 5, e003430. [CrossRef]

18. Wilhelm, J.A.; Helleringer, S. Utilization of non-Ebola health care services during Ebola outbreaks: A systematic review and meta-analysis. J. Glob. Health 2019, 9, 010406. [CrossRef]

19. UNDG. Socio-Economic Impact of Ebola Virus Disease in West African Countries; United Nations Depelopment Group Western and Central Africa: Dakar, Senegal, 2015.

20. Elston, J.W.T.; Cartwright, C.; Ndumbi, P.; Wright, J. The health impact of the 2014-15 Ebola outbreak. Public Health 2017, 143, 60-70. [CrossRef] [PubMed]

21. Chang, H.J.; Huang, N.; Lee, C.H.; Hsu, Y.J.; Hsieh, C.J.; Chou, Y.J. The Impact of the SARS Epidemic on the Utilization of Medical Services: SARS and the Fear of SARS. Am. J. Public Health 2004, 94, 562-564. [CrossRef] [PubMed]

22. Schull, M.J.; Stukel, T.A.; Vermeulen, M.J.; Zwarenstein, M.; Alter, D.A.; Manuel, D.G.; Guttmann, A.; Laupacis, A.; Schwartz, B. Effect of widespread restrictions on the use of hospital services during an outbreak of severe acute respiratory syndrome. $C m a j$ 2007, 176, 1827-1832. [CrossRef]

23. Vazquez, J.; Islam, T.; Gursky, J.; Beller, J.; Correa, D.J. Access to Care Matters: Remote Health Care Needs During COVID-19. Telemed. e-Health 2020, 27, 468-471. [CrossRef] [PubMed]

24. Ly, J.; Sathananthan, V.; Griffiths, T.; Kanjee, Z.; Kenny, A.; Gordon, N.; Basu, G.; Battistoli, D.; Dorr, L.; Lorenzen, B.; et al. FacilityBased Delivery during the Ebola Virus Disease Epidemic in Rural Liberia: Analysis from a Cross-Sectional, Population-Based Household Survey. PLoS Med. 2016, 13, e1002096. [CrossRef]

25. UNFPA. Coronavirus (2019- $n$ CoV) Guidance Document 2020; UNFPA Asia-Pacific Regional Office: Bangkok, Thailand, 2020.

26. Correa, M. Impacto del COVID-19 en la salud sexual y reproductiva. Rev. Int. Salud Matern. Fetal 2020, 5, 5-8.

27. Masresha, B.G.; Luce, R.; Weldegebriel, G.; Katsande, R.; Gasasira, A.; Mihigo, R. The impact of a prolonged ebola outbreak on measles elimination activities in Guinea, Liberia and Sierra Leone, 2014-2015. Pan Afr. Med. J. 2020, 35, 8. [CrossRef]

28. Monaghesh, E.; Hajizadeh, A. The role of telehealth during COVID-19 outbreak: A systematic review based on current evidence. BMC Public Health 2020, 20, 1193. [CrossRef]

29. Andrews, E.; Berghofer, K.; Long, J.; Prescott, A.; Caboral-Stevens, M. Satisfaction with the use of telehealth during COVID-19: An integrative review. Int. J. Nurs. Stud. Adv. 2020, 2, 100008. [CrossRef]

30. Parker, R.; Figures, E.; Paddison, C.; Matheson, J.; Blane, D.; Ford, J. Inequalities in General Practice Remote Consultations: A Systematic Review. BJGP Open 2021, 5, 1-7. [CrossRef] [PubMed]

31. Garfan, S.; Alamoodi, A.H.; Zaidan, B.B.; Al-Zobbi, M.; Hamid, R.A.; Alwan, J.K.; Ahmaro, I.Y.Y.; Khalid, E.T.; Jumaah, F.M.; Albahri, O.S.; et al. Telehealth utilization during the COVID-19 pandemic: A systematic review. Comput. Biol. Med. 2021, 138, 104878. [CrossRef]

32. Khoshrounejad, F.; Hamednia, M.; Mehrjerd, A.; Pichaghsaz, S.; Jamalirad, H.; Sargolzaei, M.; Hoseini, B.; Aalaei, S. TelehealthBased Services During the COVID-19 Pandemic: A Systematic Review of Features and Challenges. Front. Public Health 2021, 9 , 977. [CrossRef]

33. Montagnoli, C.; Zanconato, G.; Ruggeri, S.; Cinelli, G.; Tozzi, A.E. Restructuring maternal services during the COVID-19 pandemic: Early results of a scoping review for non-infected women. Midwifery 2021, 94, 102916. [CrossRef] [PubMed]

34. Olorunsaiye, C.Z.; Yusuf, K.K.; Reinhart, K.; Salihu, H.M. COVID-19 and Child Vaccination: A Systematic Approach to Closing the Immunization Gap. Int. J. Matern. Child Health AIDS 2020, 9, 381-385. [CrossRef]

35. Dhada, S.; Stewart, D.; Cheema, E.; Hadi, M.A.; Paudyal, V. Cancer services during the COVID-19 pandemic: Systematic review of patient's and caregiver's experiences. Cancer Manag. Res. 2021, 13, 5875-5887. [CrossRef] [PubMed]

36. Alqahtani, J.S.; Oyelade, T.; Aldhahir, A.M.; Mendes, R.G.; Alghamdi, S.M.; Miravitlles, M.; Mandal, S.; Hurst, J.R. Reduction in hospitalised COPD exacerbations during COVID-19: A systematic review and meta-analysis. PLoS ONE 2021, 16, e0255659. [CrossRef] [PubMed]

37. Gulliford, M.; Figueroa-Munoz, J.; Morgan, M.; Hughes, D.; Gibson, B.; Beech, R.; Hudson, M. What does "access to health care" mean? J. Health Serv. Res. Policy 2002, 7, 186-188. [CrossRef]

38. Babitsch, B.; Gohl, D.; von Lengerke, T. Re-revisiting Andersen's Behavioral Model of Health Services Use: A systematic review of studies from 1998-2011. GMS Psycho-Soc.-Med. 2012, 9, 1-15. [CrossRef]

39. Aday, L.A.; Andersen, R. A framework for the study of access to medical care. Health Serv. Res. 1974, 9, $208-220$.

40. Andersen, R.M.; Davidson, P.L. Improving Access to Care in America: Individual and Contextual Indicators. In Changing the US Health Care System: Key Issues in Health Services Policy and Management; Andersen, R., Rice, T.S., Kominski, J., Eds.; Jossey-Bass: San Francisco, CA, USA, 2001; pp. 3-31. ISBN 978-0787954048.

41. Donabedian, A. Aspects of Medical Care Administration: Specifying Requirements for Health Care; Harvard University Press: Cambridge, UK, 1973.

42. Pechansky, R.; Thomas, W. The concept of access. Definition and relationship to costumer satisfaction. Med. Care 1981, XIX, 127-140.

43. Frenk, J. El concepto y la medición de la accesibilidad. Salud Pública Mex 1985, 27, 438-453.

44. Arksey, H.; O'Malley, L. Scoping studies: Towards a methodological framework. Int. J. Soc. Res. Methodol. Theory Pract. 2005, 8 , 19-32. [CrossRef] 
45. Tricco, A.C.; Lillie, E.; Zarin, W.; O’Brien, K.K.; Colquhoun, H.; Levac, D.; Moher, D.; Peters, M.D.J.; Horsley, T.; Weeks, L.; et al. PRISMA extension for scoping reviews (PRISMA-ScR): Checklist and explanation. Ann. Intern. Med. 2018, 169, 467-473. [CrossRef] [PubMed]

46. Abebe, W.; Worku, A.; Moges, T.; Tekle, N.; Amogne, W.; Haile, T.; Mekonen, D.; Habtamu, A.; Deressa, W. Trends of follow-up clinic visits and admissions three-months before and during COVID-19 pandemic at Tikur Anbessa specialized hospital, Addis Ababa, Ethiopia: An interrupted time series analysis. BMC Health Serv. Res. 2021, 21, 731. [CrossRef]

47. Howarth, A.; Munro, M.; Theodorou, A.; Mills, P.R. Trends in healthcare utilisation during COVID-19: A longitudinal study from the UK. BMJ Open 2021, 11, e048151. [CrossRef] [PubMed]

48. Siedner, M.J.; Kraemer, J.D.; Meyer, M.J.; Harling, G.; Mngomezulu, T.; Gabela, P.; Dlamini, S.; Gareta, D.; Majozi, N.; Ngwenya, N.; et al. Access to primary healthcare during lockdown measures for COVID-19 in rural South Africa: An interrupted time series analysis. BMJ Open 2020, 10, e043763. [CrossRef]

49. Whaley, C.M.; Pera, M.F.; Cantor, J.; Chang, J.; Velasco, J.; Hagg, H.K.; Sood, N.; Bravata, D.M. Changes in Health Services Use Among Commercially Insured US Populations During the COVID-19 Pandemic. JAMA Netw. Open 2020, 3, e2024984. [CrossRef]

50. Zhang, Y.N.; Chen, Y.; Wang, Y.; Li, F.; Pender, M.; Wang, N.; Yan, F.; Ying, X.H.; Tang, S.L.; Fu, C.W. Reduction in healthcare services during the COVID-19 pandemic in China. BMJ Glob. Health 2020, 5, e003421. [CrossRef]

51. Ojetti, V.; Covino, M.; Brigida, M.; Petruzziello, C.; Saviano, A.; Migneco, A.; Candelli, M.; Franceschi, F. Non-COVID diseases during the pandemic: Where have all other emergencies gone? Medicina 2020, 56, 512. [CrossRef] [PubMed]

52. Mahmassani, D.; Tamim, H.; Makki, M.; Hitti, E. The impact of COVID-19 lockdown measures on ED visits in Lebanon. Am. J. Emerg. Med. 2021, 46, 634-639. [CrossRef] [PubMed]

53. Cano-Valderrama, O.; Morales, X.; Ferrigni, C.J.; Martín-Antona, E.; Turrado, V.; García, A.; Cuñarro-López, Y.; Zarain-Obrador, L.; Duran-Poveda, M.; Balibrea, J.M.; et al. Acute Care Surgery during the COVID-19 pandemic in Spain: Changes in volume, causes and complications. A multicentre retrospective cohort study. Int. J. Surg. 2020, 80, 157-161. [CrossRef] [PubMed]

54. Sokolski, M.; Gajewski, P.; Zymliński, R.; Biegus, J.; Berg, J.M.T.; Bor, W.; Braunschweig, F.; Caldeira, D.; Cuculi, F.; D’Elia, E.; et al. Impact of Coronavirus Disease 2019 (COVID-19) Outbreak on Acute Admissions at the Emergency and Cardiology Departments Across Europe. Am. J. Med. 2021, 134, 482-489. [CrossRef]

55. Tsioufis, K.; Chrysohoou, C.; Kariori, M.; Leontsinis, I.; Dalakouras, I.; Papanikolaou, A.; Charalambus, G.; Sambatakou, H.; Siasos, G.; Panagiotakos, D.; et al. The mystery of "missing" visits in an emergency cardiology department, in the era of COVID-19.; a time-series analysis in a tertiary Greek General Hospital. Clin. Res. Cardiol. 2020, 109, 1483-1489. [CrossRef]

56. Choi, A.; Bae, W.; Kim, K.; Kim, S. Impact of COVID-19 on the visit of pediatric patients with injuries to the emergency department in korea. Children 2021, 8, 568. [CrossRef] [PubMed]

57. Dopfer, C.; Wetzke, M.; Zychlinsky Scharff, A.; Mueller, F.; Dressler, F.; Baumann, U.; Sasse, M.; Hansen, G.; Jablonka, A.; Happle, C. COVID-19 related reduction in pediatric emergency healthcare utilization-A concerning trend. BMC Pediatr. 2020, $20,427$. [CrossRef]

58. Finkelstein, Y.; Maguire, B.; Zemek, R.; Osmanlliu, E.; Kam, A.J.; Dixon, A.; Desai, N.; Sawyer, S.; Emsley, J.; Lynch, T.; et al. Effect of the COVID-19 Pandemic on Patient Volumes, Acuity, and Outcomes in Pediatric Emergency Departments: A Nationwide Study. Pediatr. Emerg. Care 2021, 37, 427-434. [CrossRef]

59. Goldman, R.D.; Grafstein, E.; Barclay, N.; Irvine, M.A.; Portales-Casamar, E. Paediatric patients seen in 18 emergency departments during the COVID-19 pandemic. Emerg. Med. J. 2020, 37, 773-777. [CrossRef]

60. Percul, C.; Cruz, M.; Meza, A.C.; González, G.; Lerendegui, L.; Malzone, M.C.; Liberto, D.; Lobos, P.; Imach, B.E.; Moldes, J.M.; et al. Impact of the COVID-19 pandemic on the pediatric population with acute appendicitis: Experience at a general, tertiary care hospital. Arch. Argent. Pediatr. 2021, 119, 224-229. [CrossRef]

61. Yamamoto, H.; Morikawa, Y.; Hagiwara, Y.; Hataya, H. Pediatric emergency healthcare utilization during the COVID-19 pandemic in Tokyo. Pediatr. Int. 2021. [CrossRef]

62. Ball, S.; Banerjee, A.; Berry, C.; Boyle, J.R.; Bray, B.; Bradlow, W.; Chaudhry, A.; Crawley, R.; Danesh, J.; Denniston, A.; et al. Monitoring indirect impact of COVID-19 pandemic on services for cardiovascular diseases in the UK. Heart 2020, 106, 1890-1897. [CrossRef] [PubMed]

63. Kute, V.B.; Gupta, A.; Patel, H.V.; Engineer, D.P.; Banerjee, S.; Rizvi, S.J.; Mishra, V.V.; Patel, A.H.; Navadiya, V.V. The impact of COVID-19 pandemic on nephrology and transplant services and clinical training in India. Exp. Clin. Transplant. 2021, 19, 651-658. [CrossRef]

64. Morris, E.J.A.; Goldacre, R.; Spata, E.; Mafham, M.; Finan, P.J.; Shelton, J.; Richards, M.; Spencer, K.; Emberson, J.; Hollings, S.; et al. Impact of the COVID-19 pandemic on the detection and management of colorectal cancer in England: A population-based study. Lancet Gastroenterol. Hepatol. 2021, 6, 199-208. [CrossRef]

65. Pareek, A.; Patel, A.A.; Harshavardhan, A.; Kuttikat, P.G.; Pendse, S.; Dhyani, A.; Sharma, S.; Agarwal, N.; Maji, D.; Reddy, R.G.; et al. Impact of nationwide lockdown on cancer care during COVID-19 pandemic: A retrospective analysis from western India. Diabetes Metab. Syndr. Clin. Res. Rev. 2021, 15, 102131. [CrossRef] [PubMed]

66. Shi, G.; Huang, J.; Pi, M.; Chen, X.; Li, X.; Ding, Y.; Zhang, H.; Xiao, D.; Huang, G.; Ming, T.; et al. Impact of early Coronavirus Disease 2019 pandemic on pediatric cardiac surgery in China. J. Thorac. Cardiovasc. Surg. 2021, 161, 1605-1614.e4. [CrossRef] 
67. Ambrosetti, J.; Macheret, L.; Folliet, A.; Wullschleger, A.; Amerio, A.; Aguglia, A.; Serafini, G.; Prada, P.; Kaiser, S.; Bondolfi, G.; et al. Impact of the COVID-19 pandemic on psychiatric admissions to a large swiss emergency department: An observational study. Int. J. Environ. Res. Public Health 2021, 18, 1174. [CrossRef]

68. Aragona, M.; Barbato, A.; Cavani, A.; Costanzo, G.; Mirisola, C. Negative impacts of COVID-19 lockdown on mental health service access and follow-up adherence for immigrants and individuals in socio-economic difficulties. Public Health 2020, 186, 52-56. [CrossRef] [PubMed]

69. Jesenšek Papež, B.; Šošić, L.; Bojnec, V. The consequences of COVID-19 outbreak on outpatient rehabilitation services: A single-center experience in Slovenia. Eur. J. Phys. Rehabil. Med. 2021, 57, 451-457. [CrossRef]

70. Farrugia, Y.; Spiteri Meilak, B.P.; Grech, N.; Asciak, R.; Camilleri, L.; Montefort, S.; Zammit, C. The Impact of COVID-19 on Hospitalised COPD Exacerbations in Malta. Pulm. Med. 2021, 2021, 5533123. [CrossRef]

71. Burt, J.F.; Ouma, J.; Lubyayi, L.; Amone, A.; Aol, L.; Sekikubo, M.; Nakimuli, A.; Nakabembe, E.; Mboizi, R.; Musoke, P.; et al. Indirect effects of COVID-19 on maternal, neonatal, child, sexual and reproductive health services in Kampala, Uganda. BMJ Glob. Health 2021, 6, e006102. [CrossRef] [PubMed]

72. Jensen, C.; McKerrow, N.H. Child health services during a COVID-19 outbreak in KwaZulu-Natal Province, South Africa. S. Afr. Med. J. 2020, 111, 114-119. [CrossRef] [PubMed]

73. Justman, N.; Shahak, G.; Gutzeit, O.; Ben Zvi, D.; Ginsberg, Y.; Solt, I.; Vitner, D.; Beloosesky, R.; Weiner, Z.; Zipori, Y. Lockdown with a Price: The impact of the COVID-19 Pandemic on Prenatal Care and Perinatal Outcomes in a Tertiary Care Center. Isr. Med. Assoc. J. 2020, 22, 533-537. [PubMed]

74. KC, A.; Gurung, R.; Kinney, M.V.; Sunny, A.K.; Moinuddin, M.; Basnet, O.; Paudel, P.; Bhattarai, P.; Subedi, K.; Shrestha, M.P.; et al. Effect of the COVID-19 pandemic response on intrapartum care, stillbirth, and neonatal mortality outcomes in Nepal: A prospective observational study. Lancet Glob. Health 2020, 8, e1273-e1281. [CrossRef]

75. Marques-Fernandez, L.; Sharma, S.; Mannu, U.; Chong, H.P. Impact of COVID-19 on attendances for a 1stepisode of reduced fetal movements: A retrospective observational study. PLoS ONE 2021, 16, e0253796. [CrossRef]

76. Shakespeare, C.; Dube, H.; Moyo, S.; Ngwenya, S. Resilience and vulnerability of maternity services in Zimbabwe: A comparative analysis of the effect of COVID-19 and lockdown control measures on maternal and perinatal outcomes, a single-centre crosssectional study at Mpilo Central Hospital. BMC Pregnancy Childbirth 2021, 21, 416. [CrossRef]

77. Spurlin, E.E.; Han, E.S.; Silver, E.R.; May, B.L.; Tatonetti, N.P.; Ingram, M.A.; Jin, Z.; Hur, C.; Advincula, A.P.; Hur, H.C. Where Have All the Emergencies Gone? The Impact of the COVID-19 Pandemic on Obstetric and Gynecologic Procedures and Consults at a New York City Hospital. J. Minim. Invasive Gynecol. 2020, 28, 1411-1419.e1. [CrossRef]

78. Chiba, H.; Lewis, M.; Benjamin, E.R.; Jakob, D.A.; Liasidis, P.; Wong, M.D.; Navarrete, S.; Carreon, R.; Demetriades, D. “Safer at home": The effect of the COVID-19 lockdown on epidemiology, resource utilization, and outcomes at a large urban trauma center. J. Trauma Acute Care Surg. 2021, 90, 708-713. [CrossRef]

79. Horan, J.; Duddy, J.C.; Gilmartin, B.; Amoo, M.; Nolan, D.; Corr, P.; Husien, M.B.; Bolger, C. The impact of COVID-19 on trauma referrals to a National Neurosurgical Centre. Ir. J. Med. Sci. 2021, 190, 1281-1293. [CrossRef]

80. Alexander, G.C.; Tajanlangit, M.; Heyward, J.; Mansour, O.; Qato, D.M.; Stafford, R.S. Use and Content of Primary Care Office-Based vs Telemedicine Care Visits During the COVID-19 Pandemic in the US. JAMA Netw. Open 2020, 3, e2021476. [CrossRef]

81. Sato, K.; Mano, T.; Niimi, Y.; Iwata, A.; Toda, T.; Iwatsubo, T. The impact of COVID-19 pandemic on the utilization of ambulatory care for patients with chronic neurological diseases in Japan: Evaluation of an administrative claims database. Biosci. Trends 2021, 15, 219-230. [CrossRef] [PubMed]

82. Song, H.; Bergman, A.; Chen, A.T.; Ellis, D.; David, G.; Friedman, A.B.; Bond, A.M.; Bailey, J.M.; Brooks, R.; Smith-McLallen, A. Disruptions in preventive care: Mammograms during the COVID-19 pandemic. Health Serv. Res. 2021, 56, 95-101. [CrossRef] [PubMed]

83. Kahraman, A.B.; Yildiz, Y.; Çiki, K.; Akar, H.T.; Erdal, I.; Dursun, A.; Tokatli, A.; Sivri, H.S. Invisible burden of COVID-19: Enzyme replacement therapy disruptions. J. Pediatr. Endocrinol. Metab. 2021, 34, 539-545. [CrossRef] [PubMed]

84. Nicholson, E.; McDonnell, T.; Conlon, C.; Barrett, M.; Cummins, F.; Hensey, C.; McAuliffe, E. Parental Hesitancy and Concerns around Accessing Paediatric Unscheduled Healthcare during COVID-19: A Cross-Sectional Survey. Int. J. Environ. Res. Public Health 2020, 17, 9264. [CrossRef]

85. Benjamen, J.; Girard, V.; Jamani, S.; Magwood, O.; Holland, T.; Sharfuddin, N.; Pottie, K. Access to refugee and migrant mental health care services during the first six months of the COVID-19 pandemic: A canadian refugee clinician survey. Int. J. Environ. Res. Public Health 2021, 18, 5266. [CrossRef]

86. Halley, M.C.; Stanley, T.; Maturi, J.; Goldenberg, A.J.; Bernstein, J.A.; Wheeler, M.T.; Tabor, H.K. “It seems like COVID-19 now is the only disease present on Earth": Living with a rare or undiagnosed disease during the COVID-19 pandemic. Genet. Med. 2021, 23, 837-844. [CrossRef]

87. Adelekan, B.; Goldson, E.; Abubakar, Z.; Mueller, U.; Alayande, A.; Ojogun, T.; Ntoimo, L.; Williams, B.; Muhammed, I.; Okonofua, F. Effect of COVID-19 pandemic on provision of sexual and reproductive health services in primary health facilities in Nigeria: A cross-sectional study. Reprod. Health 2021, 18, 166. [CrossRef] 
88. Karavadra, B.; Stockl, A.; Prosser-Snelling, E.; Simpson, P.; Morris, E. Women's perceptions of COVID-19 and their healthcare experiences: A qualitative thematic analysis of a national survey of pregnant women in the United Kingdom. BMC Pregnancy Childbirth 2020, 20, 600. [CrossRef]

89. Khan, M.S.; Rego, S.; Rajal, J.B.; Bond, V.; Fatima, R.K.; Isani, A.K.; Sutherland, J.; Kranzer, K. Mitigating the impact of COVID-19 on tuberculosis and HIV services: A cross-sectional survey of 669 health professionals in 64 low and middle-income countries. PLoS ONE 2021, 16, e0244936. [CrossRef]

90. García-Rojo, E.; Manfredi, C.; Santos-Pérez-de-la-Blanca, R.; Tejido-Sánchez, A.; García-Gómez, B.; Aliaga-Benítez, M.; RomeroOtero, J.; Rodriguez-Antolín, A. Impact of COVID-19 outbreak on urology surgical waiting lists and waiting lists prioritization strategies in the Post-COVID-19 era. Actas Urol. Esp. 2021, 45, 207-214. [CrossRef]

91. Zambrano-Barragán, P.; Ramírez Hernández, S.; Freier, L.F.; Luzes, M.; Sobczyk, R.; Rodríguez, A.; Beach, C. The impact of COVID-19 on Venezuelan migrants' access to health: A qualitative study in Colombian and Peruvian cities. J. Migr. Health 2021, 3 , 100029. [CrossRef] [PubMed]

92. Danhieux, K.; Buffel, V.; Pairon, A.; Benkheil, A.; Remmen, R.; Wouters, E.; van Olmen, J. The impact of COVID-19 on chronic care according to providers: A qualitative study among primary care practices in Belgium. BMC Fam. Pract. 2020, 21, 255. [CrossRef] [PubMed]

93. Gichuna, S.; Hassan, R.; Sanders, T.; Campbell, R.; Mutonyi, M.; Mwangi, P. Access to Healthcare in a time of COVID-19: Sex Workers in Crisis in Nairobi, Kenya. Glob. Public Health 2020, 15, 1430-1442. [CrossRef] [PubMed]

94. Hailemariam, S.; Agegnehu, W.; Derese, M. Exploring COVID-19 Related Factors Influencing Antenatal Care Services Uptake: A Qualitative Study among Women in a Rural Community in Southwest Ethiopia. J. Prim. Care Community Health 2021, 12, 2150132721996892. [CrossRef]

95. Mizrak Sahin, B.; Kabakci, E.N. The experiences of pregnant women during the COVID-19 pandemic in Turkey: A qualitative study. Women Birth 2020, 34, 162-169. [CrossRef]

96. Dos Santos, F.L.; Souza, L.L.L.; Bruce, A.T.I.; De Almeida Crispim, J.; Arroyo, L.H.; Ramos, A.C.V.; Berra, T.Z.; Alves, Y.M.; Scholze, A.R.; Da Costa, F.B.P.; et al. Patients' perceptions regarding multidrugresistant tuberculosis and barriers to seeking care in a priority city in Brazil during COVID-19 pandemic: A qualitative study. PLoS ONE 2021, 16, e0249822. [CrossRef]

97. Ahmed, S.A.K.S.; Ajisola, M.; Azeem, K.; Bakibinga, P.; Chen, Y.-F.; Choudhury, N.N.; Fayehun, O.; Griffiths, F.; Harris, B.; Kibe, P.; et al. Impact of the societal response to COVID-19 on access to healthcare for non-COVID-19 health issues in slum communities of Bangladesh, Kenya, Nigeria and Pakistan: Results of pre-COVID and COVID-19 lockdown stakeholder engagements. BMJ Glob. Health 2020, 5, e003042. [CrossRef]

98. das Neves Martins Pires, P.H.; Macaringue, C.; Abdirazak, A.; Mucufo, J.R.; Mupueleque, M.A.; Zakus, D.; Siemens, R.; Belo, C.F. COVID-19 pandemic impact on maternal and child health services access in Nampula, Mozambique: A mixed methods research. BMC Health Serv. Res. 2021, 21, 860. [CrossRef]

99. UNFPA. COVID-19: Un Enfoque de Género. Proteger la Salud y los Derechos Sexuales y Reproductivos y Promover la Igualdad de Género; United Nations Population Fund: New York, NY, USA, 2020.

100. World Health Organization. COVID-19 Pandemic Leads to Major Backsliding on Childhood Vaccinations, New WHO, UNICEF Data Shows. Available online: https://www.who.int/news/item/15-07-2021-covid-19-pandemic-leads-to-major-backslidingon-childhood-vaccinations-new-who-unicef-data-shows (accessed on 18 July 2021).

101. Abdelbadee, A.Y.; Abbas, A.M. Impact of COVID-19 on reproductive health and maternity services in low resource countries. Eur. J. Contracept. Reprod. Health Care 2020, 25, 402-404. [CrossRef] [PubMed]

102. Kimani, R.W.; Maina, R.; Shumba, C.; Shaibu, S. Maternal and newborn care during the COVID-19 pandemic in Kenya: Recontextualising the community midwifery model. Hum. Resour. Health 2020, 18, 75. [CrossRef]

103. Chattu, V.K.; Yaya, S. Emerging infectious diseases and outbreaks: Implications for women's reproductive health and rights in resource-poor settings. Reprod. Health 2020, 17, 43. [CrossRef]

104. Murewanhema, G.; Makurumidze, R. Essential health services delivery in Zimbabwe during the COVID-19 pandemic: Perspectives and recommendations. Pan Afr. Med. J. 2020, 35, 143. [CrossRef] [PubMed]

105. Chandrasekaran, S.; Diamond-Smith, N.; Srinivasan, K.; Dalvie, S. Preparing for an Increased Need for Abortion Access in India during and after COVID-19: Challenges and Strategies. Stud. Fam. Plann. 2020, 51, 377-383. [CrossRef] [PubMed]

106. Dasgupta, A.; Kantorová, V.; Ueffing, P. The impact of the COVID-19 crisis on meeting needs for family planning: A global scenario by contraceptive methods used. Gates Open Res. 2020, 4, 102. [CrossRef]

107. Kumar, N. COVID 19 era: A beginning of upsurge in unwanted pregnancies, unmet need for contraception and other women related issues. Eur. J. Contracept. Reprod. Health Care 2020, 25, 323-325. [CrossRef]

108. Tang, K.; Gaoshan, J.; Ahonsi, B. Sexual and reproductive health (SRH): A key issue in the emergency response to the coronavirus disease (COVID-19) outbreak. Reprod. Health 2020, 17, 59. [CrossRef] [PubMed]

109. Nandagiri, R.; Coast, E.; Strong, J. COVID-19 and abortion: Making structural violence visible. Int. Perspect. Sex. Reprod. Health 2020, 46, 83-89. [CrossRef] [PubMed]

110. Onwuzurike, C.; Meadows, A.R.; Nour, N.M. Examining Inequities Associated With Changes in Obstetric and Gynecologic Care Delivery During the Coronavirus Disease 2019 (COVID-19) Pandemic. Obstet. Gynecol. 2020, 136, 37-41. [CrossRef]

111. Suh-Burgmann, E.J.; Alavi, M.; Schmittdiel, J. Endometrial Cancer Detection During the Coronavirus Disease 2019 (COVID-19) Pandemic. Obstet. Gynecol. 2020, 136, 842-843. [CrossRef] 
112. Sharma, K.A.; Zangmo, R.; Kumari, A.; Roy, K.K.; Bharti, J. Family planning and abortion services in COVID 19 pandemic. Taiwan. J. Obstet. Gynecol. 2020, 59, 808-811. [CrossRef]

113. Goyal, M.; Singh, P.; Singh, K.; Shekhar, S.; Agrawal, N.; Misra, S. The effect of the COVID-19 pandemic on maternal health due to delay in seeking health care: Experience from a tertiary center. Int. J. Gynecol. Obstet. 2021, 152, 231-235. [CrossRef]

114. Tirado, V.; Chu, J.; Hanson, C.; Ekström, A.M.; Kågesten, A. Barriers and facilitators for the sexual and reproductive health and rights of young people in refugee contexts globally: A scoping review. PLoS ONE 2020, 15, e236316. [CrossRef]

115. Maringe, C.; Spicer, J.; Morris, M.; Purushotham, A.; Nolte, E.; Sullivan, R.; Rachet, B.; Aggarwal, A. The impact of the COVID-19 pandemic on cancer deaths due to delays in diagnosis in England, UK: A national, population-based, modelling study. Lancet Oncol. 2020, 21, 1023-1034. [CrossRef]

116. Shinan-Altman, S.; Levkovich, I.; Tavori, G. Healthcare utilization among breast cancer patients during the COVID-19 outbreak. Palliat. Support. Care 2020, 18, 385-391. [CrossRef]

117. Marzo-Castillejo, M.; Guiriguet Capdevila, C.; Coma Redon, E. The impact of COVID-19 on cancer diagnosis delay: Possible consequences. Aten. Primaria 2021, 53, 102142. [CrossRef]

118. Arolas, H.P.i.; Vidal-Alaball, J.; Gil, J.; López, F.; Nicodemo, C.; Saez, M. Missing diagnoses during the COVID-19 pandemic: A year in review. Int. J. Environ. Res. Public Health 2021, 18, 5335. [CrossRef]

119. Chau, S.W.H.; Wong, O.W.H.; Ramakrishnan, R.; Chan, S.S.M.; Wong, E.K.Y.; Li, P.Y.T.; Raymont, V.; Elliot, K.; Rathod, S.; Delanerolle, G.; et al. History for some or lesson for all? A systematic review and meta-analysis on the immediate and long-term mental health impact of the 2002-2003 Severe Acute Respiratory Syndrome (SARS) outbreak. BMC Public Health 2021, $21,670$. [CrossRef]

120. Weinberger, M.; Hayes, B.; White, J.; Skibiak, J. Doing things differently: What it would take to ensure continued access to contraception during COVID-19. Glob. Health Sci. Pract. 2020, 8, 169-175. [CrossRef] [PubMed]

121. McLean, M.; Abuelaish, I. Access to reproductive health care services in countries of conflict: The double impact of conflict and COVID-19. Med. Confl. Surviv. 2020, 36, 283-291. [CrossRef] [PubMed]

122. Abdela, S.G.; Van Griensven, J.; Seife, F.; Enbiale, W. Neglecting the effect of COVID-19 on neglected tropical diseases: The Ethiopian perspective. Trans. R. Soc. Trop. Med. Hyg. 2020, 114, 730-732. [CrossRef] [PubMed]

123. UNFPA; Avenir Health; John Hopkins University; Victoria University. Impact of the COVID-19 Pandemic on Family Planning and Ending Gender-Based Violence, Female Genital Mutilation and Child Marriage; United Nations Population Fund: New York, NY, USA, 2020.

124. Organización Mundial de la Salud Los Servicios de Salud Mental se Están Viendo Perturbados por la COVID-19 en la Mayoría de los Países, Según un Estudio de la OMS. Available online: https:/ / www.who.int/es/news/item/05-10-2020-covid-19-disruptingmental-health-services-in-most-countries-who-survey (accessed on 12 July 2021).

125. Karos, K.; McParland, J.L.; Bunzli, S.; Devan, H.; Hirsh, A.; Kapos, F.P.; Keogh, E.; Moore, D.; Tracy, L.M.; Ashton-James, C.E. The social threats of COVID-19 for people with chronic pain. Pain 2020, 161, 2229-2235. [CrossRef]

126. Diamond, L.C.; Jacobs, E.A.; Karliner, L. Providing equitable care to patients with limited dominant language proficiency amid the COVID-19 pandemic. Patient Educ. Couns. 2020, 103, 1451-1452. [CrossRef] [PubMed]

127. Betancourt, J.A.; Rosenberg, M.A.; Zevallos, A.; Brown, J.R.; Mileski, M. The Impact of COVID-19 on Telemedicine Utilization Across Multiple Service Lines in the United States. Healthcare 2020, 8, 380. [CrossRef]

128. Fryer, K.; Delgado, A.; Foti, T.; Reid, C.N.; Marshall, J. Implementation of Obstetric Telehealth During COVID-19 and Beyond. Matern. Child Health J. 2020, 24, 1104-1110. [CrossRef] [PubMed]

129. Contreras, C.M.; Metzger, G.A.; Beane, J.D.; Dedhia, P.H.; Ejaz, A.; Pawlik, T.M. Telemedicine: Patient-Provider Clinical Engagement During the COVID-19 Pandemic and Beyond. J. Gastrointest. Surg. 2020, 24, 1692-1697. [CrossRef] [PubMed]

130. Ramaswamy, A.; Yu, M.; Drangsholt, S.; Ng, E.; Culligan, P.J.; Schlegel, P.N.; Hu, J.C. Patient satisfaction with telemedicine during the COVID-19 pandemic: Retrospective cohort study. J. Med. Internet Res. 2020, 22, e20786. [CrossRef]

131. Aiken, A.R.A.; Starling, J.E.; Gomperts, R.; Tec, M.; Scott, J.G.; Aiken, C.E. Demand for Self-Managed Online Telemedicine Abortion in the United States During the Coronavirus Disease 2019 (COVID-19) Pandemic. Obstet. Gynecol. 2020, 136, 835-837. [CrossRef]

132. Eberly, L.A.; Kallan, M.J.; Julien, H.M.; Haynes, N.; Khatana, S.A.M.; Nathan, A.S.; Snider, C.; Chokshi, N.P.; Eneanya, N.D.; Takvorian, S.U.; et al. Patient Characteristics Associated With Telemedicine Access for Primary and Specialty Ambulatory Care During the COVID-19 Pandemic. JAMA Netw. Open 2020, 3, e2031640. [CrossRef]

133. Mann, D.M.; Chen, J.; Chunara, R.; Testa, P.A.; Nov, O. COVID-19 transforms health care through telemedicine: Evidence from the field. J. Am. Med. Inform. Assoc. 2020, 27, 1132-1135. [CrossRef]

134. Limaye, M.A.; Lantigua-Martinez, M.; Trostle, M.E.; Penfield, C.A.; Conroy, E.M.; Roman, A.S.; Mehta-Lee, S.S. Differential Uptake of Telehealth for Prenatal Care in a Large New York City Academic Obstetrical Practice during the COVID-19 Pandemic. Am. J. Perinatol. 2020, 1, 18-20. [CrossRef]

135. Futterman, I.; Rosenfeld, E.; Toaff, M.; Boucher, T.; Golden-Espinal, S.; Evans, K.; Clare, C.A. Addressing Disparities in Prenatal Care via Telehealth during COVID-19: Prenatal Satisfaction Survey in East Harlem. Am. J. Perinatol. 2021, 38, 88-92. [CrossRef]

136. Schweiberger, K.; Hoberman, A.; Iagnemma, J.; Schoemer, P.; Squire, J.; Taormina, J.; Wolfson, D.; Ray, K.N. Practice-level variation in telemedicine use in a pediatric primary care network during the COVID-19 pandemic: Retrospective analysis and survey study. J. Med. Internet Res. 2020, 22, e24345. [CrossRef] 
137. Riley, T.; Sully, E.; Ahmed, Z.; Biddlecom, A. Estimates of the Potential Impact of the COVID-19 Pandemic on Sexual and Reproductive Health in Low- and Middle-Income Countries. Int. Perspect. Sex. Reprod. Health 2020, 46, 73-76. [CrossRef] [PubMed]

138. Lazzerini, M.; Barbi, E.; Apicella, A.; Marchetti, F.; Cardinale, F.; Trobia, G. Delayed access or provision of care in Italy resulting from fear of COVID-19. Lancet Child Adolesc. Health 2020, 4, 10-11. [CrossRef]

139. Shayganfard, M.; Mahdavi, F.; Haghighi, M.; Bahmani, D.S.; Brand, S. Health anxiety predicts postponing or cancelling routine medical health care appointments among women in perinatal stage during the COVID-19 lockdown. Int. J. Environ. Res. Public Health 2020, 17, 8272. [CrossRef] [PubMed]

140. Mauro, V.; Lorenzo, M.; Paolo, C.; Sergio, H. Treat all COVID 19-positive patients, but do not forget those negative with chronic diseases. Intern. Emerg. Med. 2020, 15, 787-790. [CrossRef] [PubMed]

141. Pant, S.; Koirala, S.; Subedi, M. Access to Maternal Health Services during COVID-19. Eur. J. Med. Sci. 2020, 2, 48-52. [CrossRef]

142. Nab, M.; van Vehmendahl, R.; Somers, I.; Schoon, Y.; Hesselink, G. Delayed emergency healthcare seeking behaviour by Dutch emergency department visitors during the first COVID-19 wave: A mixed methods retrospective observational study. BMC Emerg. Med. 2021, 21, 56. [CrossRef]

143. Jones, S.A.; Gopalakrishnan, S.; Ameh, C.A.; White, S.; Van Den Broek, N.R.; Van Den Broek, N.R. 'Women and babies are dying but not of Ebola': The effect of the Ebola virus epidemic on the availability, uptake and outcomes of maternal and newborn health services in Sierra Leone. BMJ Glob. Health 2016, 1, 65. [CrossRef]

144. Townsend, R.; Chmielewska, B.; Barratt, I.; Kalafat, E.; van der Meulen, J.; Gurol-Urganci, I.; O’Brien, P.; Morris, E.; Draycott, T.; Thangaratinam, S.; et al. Global changes in maternity care provision during the COVID-19 pandemic: A systematic review and meta-analysis. EClinicalMedicine 2021, 37, 100947. [CrossRef]

145. Germain, S.; Yong, A. COVID-19 Highlighting Inequalities in Access to Healthcare in England: A Case Study of Ethnic Minority and Migrant Women. Fem. Leg. Stud. 2020, 28, 301-310. [CrossRef] [PubMed] 